\title{
PLANEJAMENTO URBANO EM GOIÂNIA: A câmera participante e um estudo pelas margens
}

\author{
Pedro Henrique Baima Paiva ${ }^{1}$
}

\section{Introdução}

Visitei Goiânia em 1937 (...) ali nos sentíamos como numa estação de trem ou num hospital, sempre passageiros, e nunca residentes (LÉVI-STRAUSS 1996:132).

A Goiânia que o antropólogo Claude Lévi-Strauss visitou em 1937 e relatou em Tristes Trópicos se transformou ao longo desses anos. A cidade planejada e modernista que nasceu no centro oeste do país, durante esse tempo foi escolhida por pessoas vindas de vários Estados para trabalhar e viver. Contudo, para algumas dessas pessoas que há mais de 60 anos lutam pela escritura de suas casas, essa sensação de "passageiro", vez ou outra ainda volta à lembrança.

Este é o caso dos moradores da Ocupação do Jardim Botânico (OJB), que mais uma vez enfrentam a ameaça de despejo após o anúncio de projetos urbanísticos para a região. Construída às margens do Botafogo, córrego que historicamente acolheu muitas famílias vindas para a construção da cidade planejada, a OJB trava uma disputa com a prefeitura em busca da regularização fundiária das casas no mesmo momento em que o setor imobiliário lança seu olhar para o potencial de valorização da área e pressiona o poder público por intervenções.

Ao analisar o diálogo entre a prefeitura, os moradores e os investidores imobiliários considerando-o como sugere Herzfeld (1991), um debate cultural na prática social, procuro contribuir com o estudo de processos urbanísticos e de intervenções urbanas aprofundando o olhar para a relação de familiaridade que os moradores têm com os lugares. Conhecer o saber local a partir das dinâmicas dos moradores, seus valores e suas memórias pode fornecer informações importantes sobre os lugares, que devem ser incorporadas ao saber técnico e especializado do ambiente político e burocrático do planejamento das cidades.

Para tanto, precisamos considerar que talvez uma das formas mais eficientes de colonização seja a do saber. A maneira como nos relacionamos com tudo a nossa volta

\footnotetext{
${ }^{1}$ Universidade Federal de Goiás; Agência Municipal de Meio Ambiente de Goiânia, Brasil.
} 
depende muito dos significados, valores e conceitos que atribuímos ao que existe no mundo material e espiritual. Entretanto, para Shiva (2003:24) "os sistemas ocidentais de saber têm sido considerados universais e têm progressivamente se expandido no mundo a partir de uma visão dominante, mas que não passam de uma versão globalizada de uma tradição local extremamente provinciana".

Todavia, ao se considerar o único "científico" e universal, isto é, um saber neutro que não é determinado pela mediação social, o saber ocidental eurocêntrico se legitima frente aos outros. Esse rótulo atribui a ele uma espécie de sacralidade ou imunidade social e um sentido quase providencial de destino histórico. Para Stam (2003), com a globalização, esse saber intensificou sua apropriação da produção cultural, intelectual e material de não europeus, negando ao mesmo tempo, tanto os feitos destes últimos quanto a apropriação realizada, consolidando assim, seu sentido de si mesmo e glorificando sua própria antropofagia cultural.

Isso porque o saber ocidental moderno segundo Shiva (2003) é um sistema cultural que se coloca acima da cultura e da política, sua relação com o projeto de desenvolvimento econômico é invisível e por isso se tornou parte de um processo de legitimação mais efetivo para homogeneização do mundo e erosão de sua riqueza ecológica e cultural, principalmente no Estado moderno, que para Quijano (2000), é produto da distribuição democrática do controle sobre os recursos de produção e influência às instituições do governo. Trata-se de um padrão de dominação, exploração e conflito entre os habitantes que estão em posições desiguais no controle dos recursos.

É claro que a história e os conceitos trazem uma intencionalidade que precisa ser ressaltada. A própria relação de desenvolvimento com modernização implica numa relação histórica, faz parte de uma ideia eurocêntrica em plena crise, isso porque a versão europeia da modernidade é em perspectiva, a outra cara da colonialidade no resto do mundo. Entretanto, Ribeiro (1992) pressupõe que as diversas mudanças nas formas de reprodução da vida política, econômica, social e cultural na contemporaneidade têm levado a uma reformulação da noção de desenvolvimento.

É nesse contexto que a cidade de Goiânia, planejada e construída na década de 1930 como símbolo da ruptura do tradicional em busca da modernidade, se torna um ótimo caso para análise. A capital do Estado de Goiás tem experimentado o que (Harvey, 
2014) chamou de desenvolvimento incoerente e insípido que ganhou legitimidade no movimento chamado "novo urbanismo" e que enalteceu a venda da comunidade e do "estilo butique" como modo de vida, criando um produto feito por agentes imobiliários para satisfazer os sonhos urbanos.

A chegada dos arranha-céus multifuncionais, dos condomínios e do consumismo irracional tornou muitas cidades lugares para uma existência alienada, conflituosa e sempre ansiosa por novas construções. Para (Harvey, 2014), também lugar para o sombrio desespero da marginalização, da repressão policial e da juventude ociosa perdida no tédio do aumento do desemprego nos subúrbios.

Por outro lado, lugar onde um forte espírito de cooperação floresce em muitos movimentos sociais que buscam a transformação da vida urbana, demonstrando, conforme (Barbosa, 2002:102) “as contradições sociais próprias das relações entre capital e trabalho manifestadas em lutas sociais e nas relações políticas entre as forças sociais que controlam o governo". A intensificação desses movimentos sugere que houve uma reafirmação do capitalismo no final do século $\mathrm{XX}$ induzindo as cidades a ampliarem a rentabilidade do capital e tornando-as elemento-chave em direção a um novo modelo de produção global que transforma os espaços urbanos.

Concentração de mão de obra e mercado consumidor, as cidades modernas tornaram-se lugares especiais para o investimento capitalista e a geração de capital excedente, que conforme (Harvey, 2014) promove uma íntima relação entre o capitalismo e a urbanização, pois a concentração de mão de obra com oferta de baixos salários garante mais lucro por meio da mais-valia e porque as cidades absorvem a produção de excedentes exigidos pela urbanização, pela suburbanização, e pela criação de novos mercados e estilos de vida, fazendo a cidade um grande negócio capitalista.

Em Goiânia, a arquitetura e o projeto urbano tornaram-se essenciais na concepção da imagem da cidade e do seu Marketing para atrair moradores e investimentos, para (Arantes, 2015), com destaque para o caráter ambiental que sempre foi decisivo no discurso e na formação da imagem da capital. Nesse sentido, parques urbanos tornaramse sinônimos de qualidade de vida e de desenvolvimento sustentável, e são equipamentos públicos disputados pela população, pela prefeitura e por investidores imobiliários. 
Nesse contexto, me proponho olhar a urbanização de Goiânia e o papel do planejamento urbano nesse negócio capitalista por um viés decolonial, isto é, sob a perspectiva de moradores de uma ocupação, considerando a colonialidade do saber que está fortemente presente em nossa sociedade e pode ser vista na história, nas memórias, na cultura, nas ciências, na política e etc.

Isto porque em muitos casos, para a lógica materialista presente no planejamento urbano contemporâneo, a diversidade é vista como um "caos" e a homogeneidade fabricada como a "ordem", o que escamoteia um cenário de disputa entre as camadas sociais menos abastadas, sitiadas em áreas sem infraestrutura e as mais abastadas que circulam e vivem em suas "ilhas de primeiro mundo", monopolizando o ordenamento das cidades a fim de manter seu poder, o que torna a localização, o principal elemento na análise da dinâmica interna das cidades juntamente com o valor do solo urbano, ou seja, as melhores localizações possuem um preço mais alto (Correa, 2009).

Localizações caras que se tornam o que Sharon Zukin define como "paisagens de poder”. A paisagem é uma ordem espacial imposta ao ambiente, natural e construído que é, portanto, sempre socialmente construída e ordenada pelo poder das instituições sociais dominantes. "A paisagem dá forma material a uma assimetria entre o poder econômico e o cultural". O poder da paisagem é construído ao longo do tempo de maneira simbólica, cultural e arquitetônica, o que reflete no valor econômico do solo urbano e faz da arquitetura o capital do simbolismo (Zukin, 2000:84).

Em Goiânia, o mercado imobiliário age sem muitas dificuldades na ocupação e valorização da terra e tem alterado durante décadas o seu plano original tornando-a uma cidade cada vez mais polinucleada. Como os agentes do setor imobiliário destacam-se como os principais atores no processo de expansão urbana, novas centralidades são criadas como localizações privilegiadas promovendo especulação imobiliária, desapropriações e gentrificação.

É bom observar que a segregação espacial é um problema antigo, Gilberto Freyre já na década de 1930 procurou descrever em seu livro, Sobrados e Mucambos, como ocorreu a mudança da aristocracia e dos ex-escravos, após a abolição da escravatura, da zona rural para as cidades, os primeiros se mudando para os sobrados e os ex-escravos para os casebres de palha nos bairros mais pobres das áreas urbanas. 
Segundo Freyre (1998), desde aquela época já era notória a distribuição humana desigual, os ricos construíam suas casas em solo bom e seco, enquanto para os pobres, principalmente os mestiços, mulatos ou negros sobrava a lama. Quando construíam em locais secos, em chão enxuto e saneado, logo eram enxotados para vir então os ricos e levantarem suas casas de pedra e cal. Os mucambos então apareceriam em outros lugares, em outros trechos de lama dentro de outros mangues.

As classes abastadas monopolizam o ordenamento da cidade, criando imagens e funcionalizando-a a fim de manter seu poder. O meio ambiente se torna nessa lógica um equipamento público bastante valorizado no mercado. No lançamento dos condomínios fechados em volta dos parques urbanos, o Marketing ambiental impõe às pessoas a necessidade de comprar os recursos naturais como o ar puro e os bosques, além da proteção contra a violência e contra o caos dos centros urbanos (Correa, 2009).

Se a cidade é uma mercadoria, outro processo lucrativo são as "requalificações" de áreas desvalorizadas, que para Jacobs (2003), nada mais são que residências de classe média e alta ocupando grande extensão do solo urbano como "ilhas urbanas", "cidades dentro da cidade", partes desse "novo conceito de vida urbana", segundo a publicidade imobiliária.

Nesse sentido, o estudo da urbanização das cidades pode nos trazer indícios importantes acerca dos problemas vividos pelas populações urbanas como depressão, violência, favelização, guetoização, degradação do ambiente e do tecido urbano. Pode também nos ajudar a antecipar as consequências da megalopolização, isto é, o crescimento desordenado das cidades com poluição e com parte da população vivendo em áreas irregulares como cortiços, invasões, favelas e também populações chamadas "marginalizadas", "periféricas" ou "excluídas" vivendo em habitações improvisadas e ilegais (Freitag, 2006).

Atualmente junto ao crescimento das grandes cidades, cresce também a uma taxa de $25 \%$ ao ano a população mundial que vive em favelas, aproximadamente $31,6 \%$ da população mundial, quase um bilhão de pessoas. Em Goiânia, segundo dados do IBGE, Instituto Brasileiro de Geografia e Estatística, em 2012, 15\% do território estava ocupado com loteamentos irregulares. Além da exclusão social, a correlação entre urbanização e aumento da renda per capita promove outros problemas, como por exemplo, o 
aumentando da pressão sobre as riquezas ambientais, os desafios de mobilidade, e a qualidade de vida e de saúde (Leite; Award, 2012).

Embora o Banco Mundial e o Fundo Monetário Internacional insistam que a proliferação de favelas pelo mundo seja culpa de maus governos e não da globalização e das desigualdades, a superurbanização com espalhamento, degradação ambiental e os perigos urbanos se contrapõem a esses discursos que não lançam luz sobre os processos de pauperização urbana dos trabalhadores e o aumento do emprego informal.

Em Goiânia, as famílias que vieram em grande número para a construção da cidade e de grandes obras como as do Estádio Serra Dourada, do Autódromo Internacional e do shopping Flamboyant, sem alternativas para morar, acabaram ocupando as margens dos córregos e por lá construíram suas casas, se estabelecendo, vivendo e construindo a cidade que conhecemos hoje, conforme apontam (Arantes, 2015), (Oliveira e Peixoto, 2009) e relatos de moradores.

Atualmente, lugares disputados para a construção de condomínios de luxo como as margens dos parques, córregos e lagos da cidade, se tornam lugares de dissenso e disputa entre moradores, a prefeitura e empresas imobiliárias. Dissenso que conforme (Leite, 2007) são formas distintas de atribuição de sentido aos lugares.

A cidade é sempre o resultado convergente de distintas influências formais e cotidianas, o que proporciona para Leite (2007), usos e contra-usos dos espaços urbanos. Embora o autor trabalhe com a ideia de usos e contra-usos em espaços enobrecidos e em processo de gentrificação, lanço mão dos mesmos conceitos para estudar uma região que se pretende enobrecer e que teme o processo de gentrificação, a Ocupação Jardim Botânico, mas tomo como "usos" a ocupação feita pelos moradores atuais e de "contrausos" a ocupação pretendida pela prefeitura e os investidores imobiliários.

Segundo Leite (2007) e De Certeau (2001), os lugares são polissêmicos, isto é, possuem vários sentidos e são constituídos a partir de "estratégias" e de "táticas". As “estratégias" são fruto do poder especializado, se afirmam como práticas organizadoras da cidade e implicam a construção de uma visão totalizante e homogênea, enquanto as "táticas" são movimentos heterogêneos e imprevisíveis organizadas pela ausência de poder, ou pelos "sem poder", que ocorre no interior de espaços urbanos, subvertendo seus sentidos estratégicos. 
Vivemos em cidades construídas por inúmeros atores, que convivem com as práticas organizadoras da cidade habitada. Essa rede de regras, valores e significados que compõem uma história múltipla, de múltiplos autores, é formada em fragmentos de trajetórias e de alterações de espaços. E nesse caso, as experiências antropológicas favorecem um olhar que escapa às totalizações imaginárias do olhar, às práticas estranhas ao espaço "geométrico" ou "geográfico" das construções visuais ou teóricas. Expõe para o planejamento urbano, as cidades transmutantes ou metafóricas que convivem com a lógica da cidade planejada e visível (De Certeau, 2001).

Nos próximos capítulos procurarei discutir a possibilidade de políticas de urbanização mais justas a partir da etnografia realizada na OJB e após a prefeitura e representantes do setor imobiliário apresentaram uma proposta de Operação Urbana Consorciada para os moradores da capital.

No primeiro capítulo vou apresentar como me inspirei na técnica da câmera participante para realizar uma observação participante na OJB, também abordarei como a câmera influenciou na minha relação com moradores e permitiu a superação de algumas dificuldades do campo. Como agente da prefeitura e pesquisador, também é no primeiro capítulo que apresento como esse duplo lugar de fala refletiu nas minhas ações na prefeitura e no meu convívio com os moradores.

O segundo capítulo se preocupa em apresentar os moradores e as moradoras da OJB, assim como suas relações com a região, com o Córrego Botafogo e com a mata do Jardim Botânico. As narrativas biográficas nesse capítulo são tomadas como um processo narrativo de construção social, com destaque para as histórias da origem da ocupação e de suas transformações.

\section{Capítulo I: A Câmera Participante na Antropologia da Cidade}

Magnani propõe que a antropologia $n a$ cidade, isto é, o estudo de vários objetos de pesquisa na cidade como religião, política, gênero, raça e etc, pode caminhar na direção de construir uma nova perspectiva $d a$ cidade, tornando a própria cidade como objeto de pesquisa e contribuindo com novos modelos de entendimento. Para tanto,

o pesquisador não apenas busca apreender o significado do arranjo do nativo, mas ao perceber esse significado e conseguir descrevê-lo agora nos seus termos (dele, analista), é capaz de atestar sua lógica e incorporá-la de acordo com os padrões de seu próprio aparato intelectual e até mesmo de seu sistema de valores (Magnani, 2012:264). 
A partir dessa premissa, o estudo do debate cultural entre moradores e a prefeitura de Goiânia, que disputam o direito à terra numa região da cidade, as entrevistas e as visitas feitas em companhia de Jorge à moradores associados ao ILOGU $^{2}$, tornaram-se um importante material para a pesquisa da cidade (Mapa 1).

Como os lugares são sempre imaginados no contexto de determinações políticas, econômicas e de suas lógicas próprias, existem tensões importantes quando esses lugares imaginados a distância tornam-se lugares vividos (Gupta; Ferguson, 2000). Portanto, a partir do estudo antropológico na cidade, na Ocupação Jardim Botânico, buscou-se o estudo da cidade, com foco no dissenso, isto é, nas formas distintas de atribuição de sentido aos lugares, analisando a maneira em que os moradores e o poder público se apropriam ou imaginam os lugares dessa região.

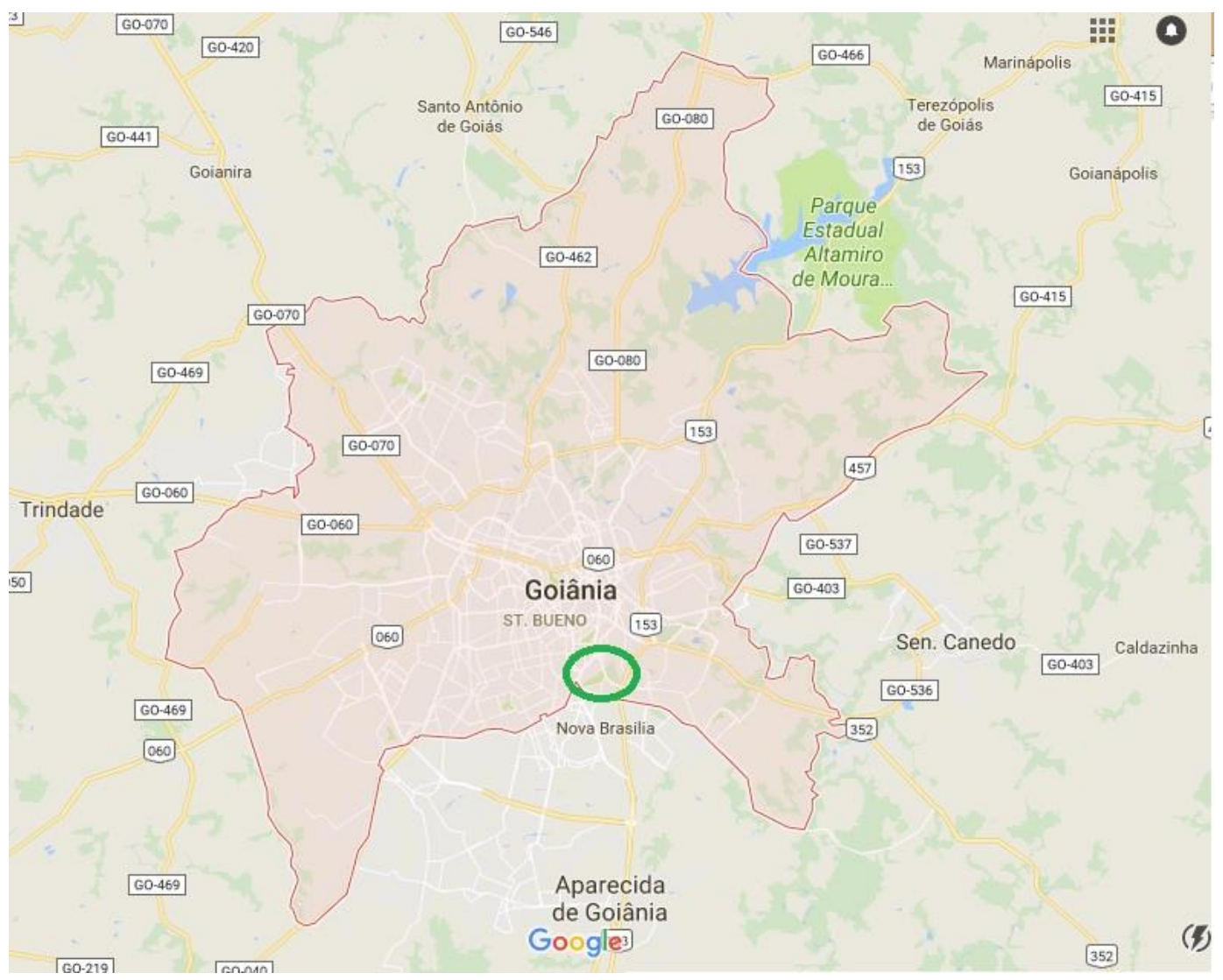

Mapa 1: Mapa de Goiânia. Destaque para a região do Jardim Botânico e da Ocupação Jardim Botânico no círculo de cor verde. Imagem do Google.

\footnotetext{
${ }^{2}$ Segundo a página na internet do ILOGU: www.ilogu.org.br, o instituto está registrado como pessoa jurídica de direito privado e surgiu da necessidade coletiva de ajudar os moradores da comunidade onde o instituto está localizado, na Avenida Segunda Radial, número 794 bairro Vila Redenção em Goiânia, Goiás, ameaçados de despejo pela prefeitura.
} 
A primeira ida a campo aconteceu em abril de 2014. Naquela ocasião eu estava escrevendo uma monografia para conclusão do curso de graduação em Ciências Sociais e em campo, realizando minha primeira experiência de cunho etnográfico. Tomei como referência para esse trabalho, a área delimitada pela prefeitura de Goiânia como objeto de uma parceria público-privada na região do entorno do Jardim Botânico abrangendo sete bairros: Setor Pedro Ludovico, Vila Izabel, Vila Maria José, Vila Redenção, Areião I, Jardim Santo Antônio e Jardim das Esmeraldas, projeto que ficou conhecido como Operação Urbana Consorciada Jardim Botânico (Mapa 2).

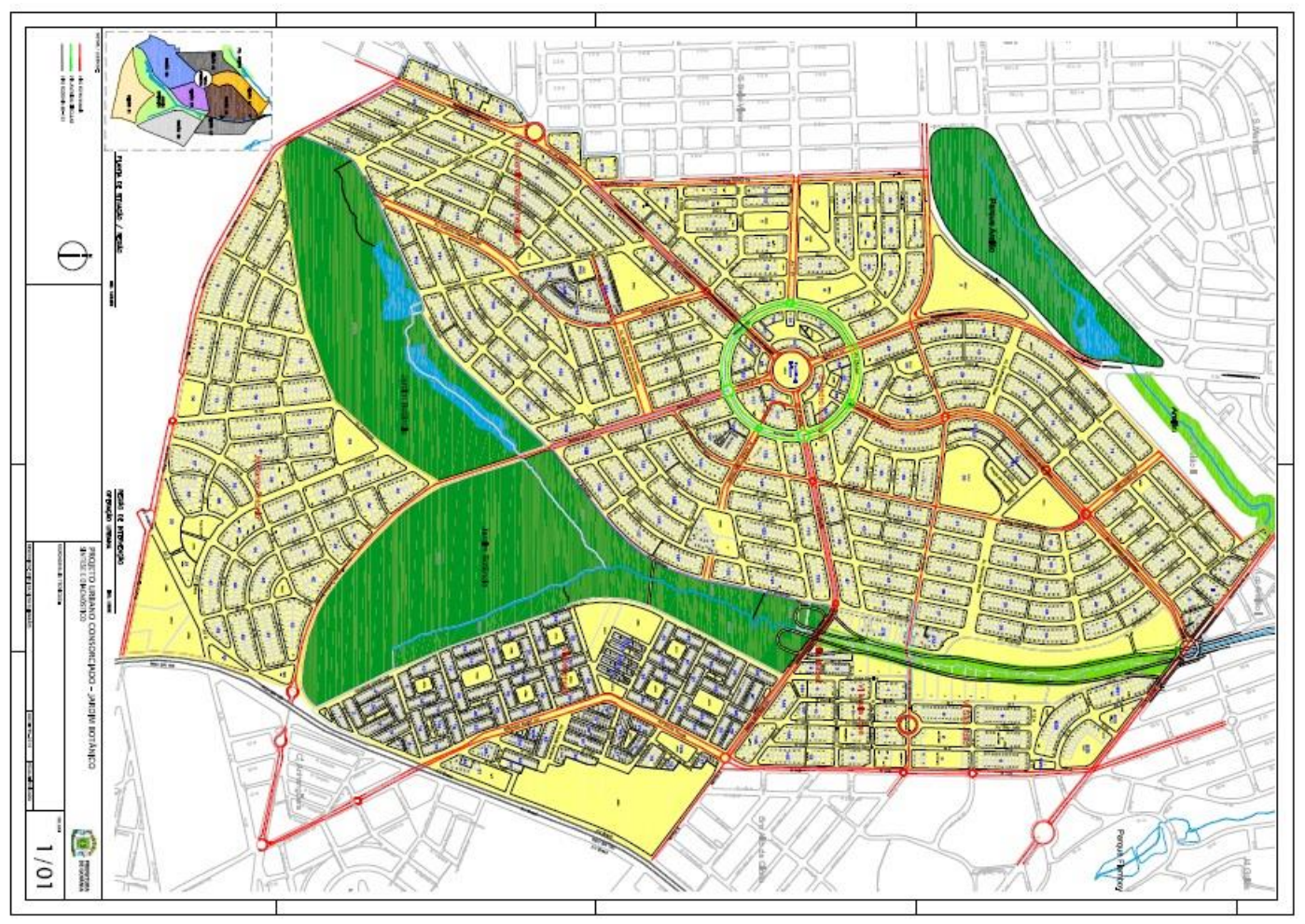

Mapa 2: Região sugerida para a Operação Urbana Consorciada Jardim Botânico. Destaque para o Terminal Isidória ao centro, rodeado por um círculo verde na imagem, a Avenida Circular. As linhas de cor vermelha representam as avenidas chamadas de Radiais que convergem para o terminal. De cor verde escura dois parques: o maior à esquerda na imagem, cortado pela Avenida Terceira Radial é o Jardim Botânico, e à direita da imagem e menor, o Parque Areião. Imagem cedida pela Prefeitura.

Percorri ruas e calçadas, conversei com moradores e usuários, e busquei observálos e entrevistá-los em todos esses bairros. Não pude deixar de observar que as calçadas são em sua maioria muito ruins, com o calçamento danificado ou ausente, sem padrão de forma e de material, são construídas com rampas de todas as inclinações para dar acesso aos veículos, e que as árvores plantadas em alinhamento com os postes com fiação área 
de luz e telefone demandam cortes em seus galhos incrivelmente horríveis, como em muitos outros lugares da cidade.

As ruas no entorno do Jardim Botânico são em sua maioria estreitas, movimentadas e repletas de quebra molas feitos pelos moradores com o objetivo de diminuir a velocidade dos veículos e os acidentes. Não contam com sistema adequado de drenagem, provocando enchentes em dias de chuvas fortes, e erosões nas nascentes do córrego Botafogo e no Jardim Botânico. Produzi também durante esse trabalho um pequeno acervo fotográfico das pessoas e de paisagens no afã de registrar instantâneos da prática social e das paisagens arquitetônicas, urbanísticas e culturais que estão em constante transformação (Figura 1).

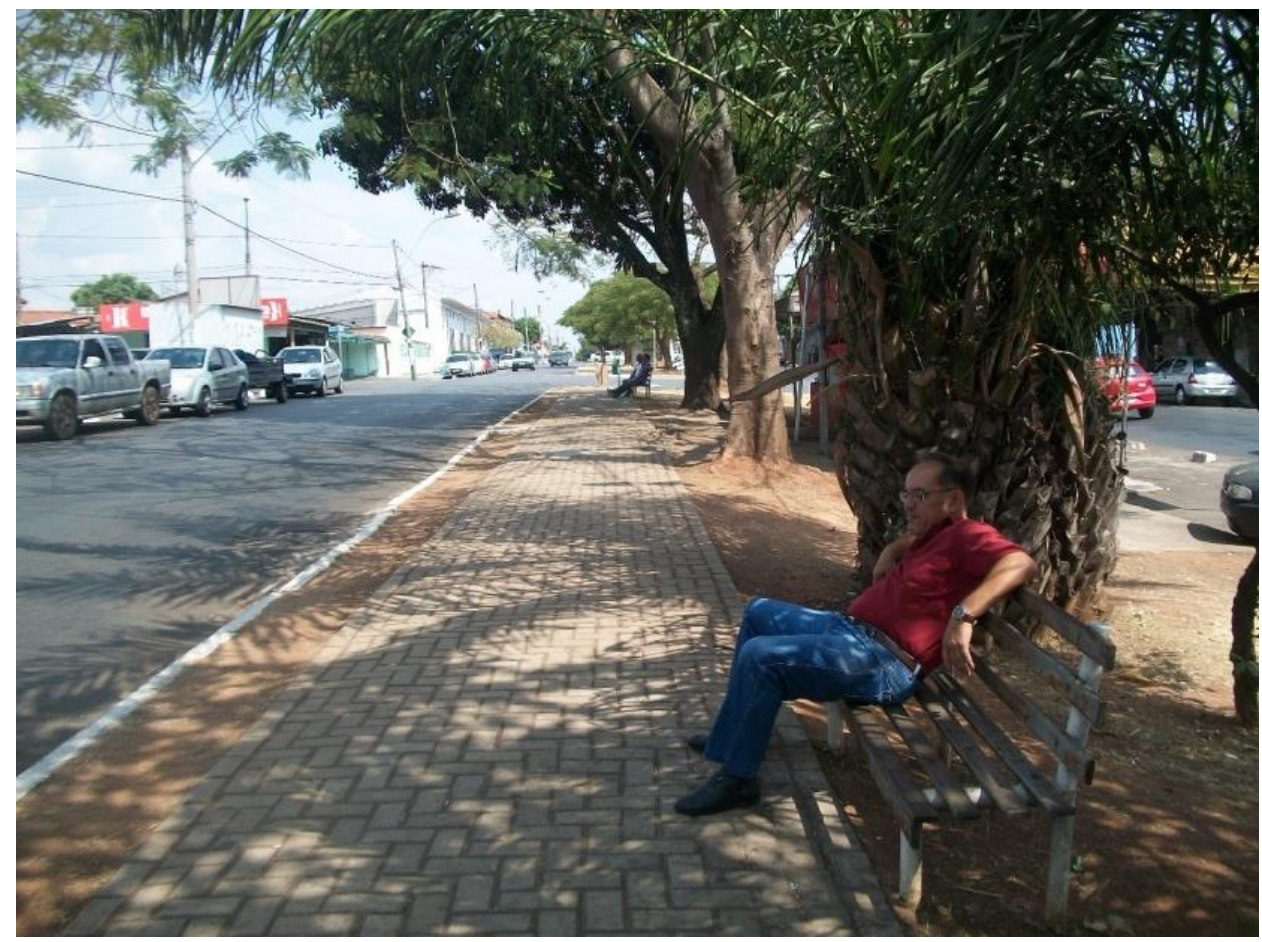

Figura 1: Setor Vila Redenção. Foto do autor.

A segunda incursão a campo aconteceu em dezembro de 2014 quando conheci Jorge Hércules, presidente, e Ozias Vieira, vice-presidente do ILOGU, Instituto Pró Logística Urbana (Figura 2), em uma reunião com os moradores representando meu então chefe, presidente da Agência Municipal de Meio Ambiente de Goiânia (AMMA), Professor Pedro Wilson. Saí dessa reunião como um contato dos moradores com a AMMA, e consequentemente com Pedro Wilson, político bastante conhecido na região, 
lembrado por muitos moradores como o prefeito que trouxe o asfalto para a Alameda Jardim Botânico.

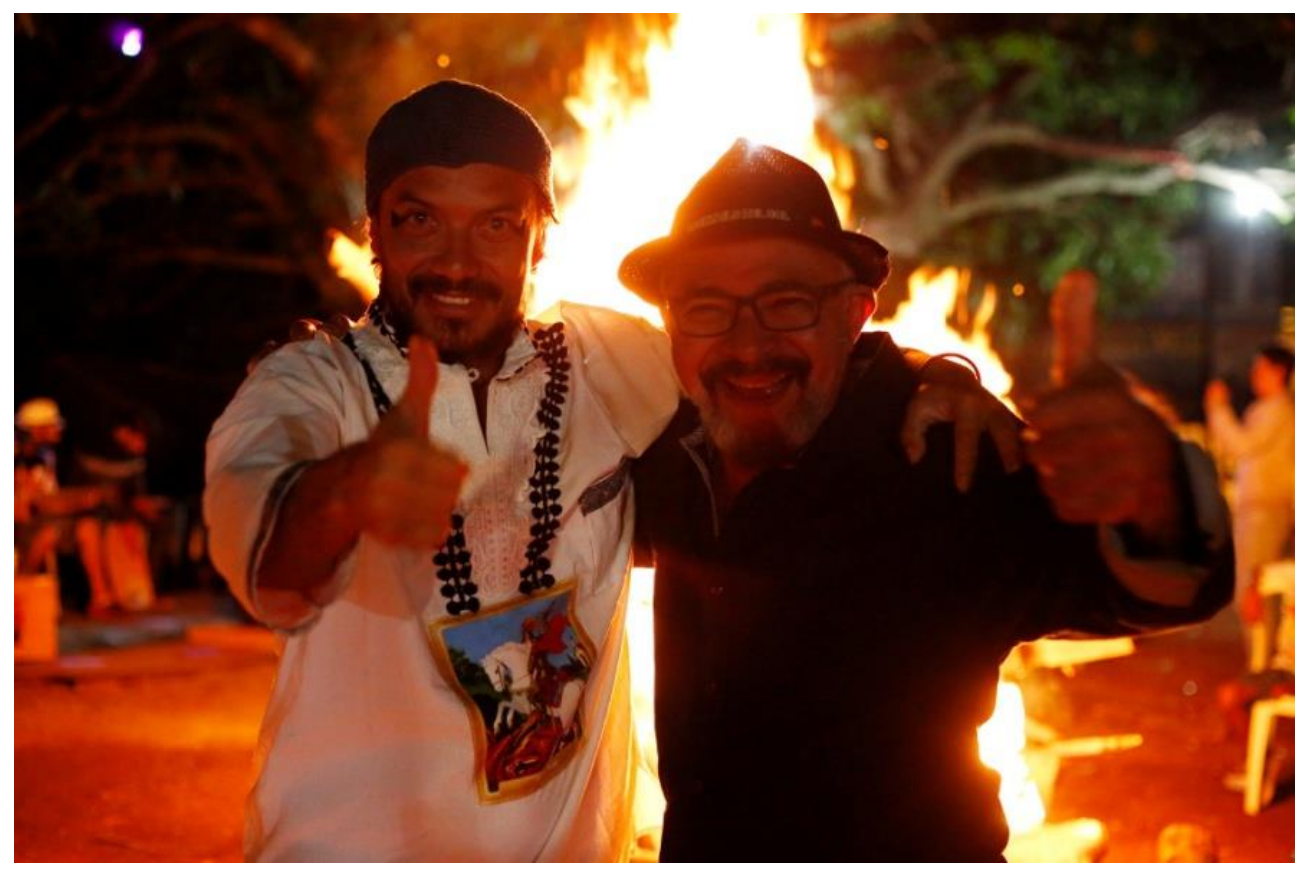

Figura 2: Jorge à esquerda e Ozias à direita na imagem em uma festa junina no ILOGU. Foto do autor.

Professor Pedro Wilson, como gosta de ser chamado, segundo a Wikipédia, enciclopédia livre da internet, nasceu em 24 de fevereiro de 1942 na cidade de Marzagão, interior de Goiás. É advogado, professor universitário, sociólogo e político brasileiro filiado ao Partido dos Trabalhadores (PT). Graduado em direito e em ciências sociais pela Universidade Federal de Goiás, foi professor da Pontifícia Universidade Católica de Goiás, sendo que entre 1985 e 1988 exerceu o cargo de Reitor dessa mesma instituição. Foi um dos fundadores do PT em Goiás em 1980 e sua biografia política contabiliza mandatos de vereador da cidade de Goiânia (1993 - 1995), deputado federal por Goiás (1995 - 2000; 2007 - 2011), e prefeito de Goiânia (2001 - 2004).

Foi nessa reunião na ocupação representando o então presidente da AMMA Professor Pedro Wilson que conheci o ILOGU. Quem me recebeu logo na entrada foi Ozias. Sua primeira pergunta a mim foi: Você é engenheiro da AMMA? E eu respondi: 
Não, sou biólogo $o^{3}$. Seu sorriso e seus olhos arregalados denunciaram no mesmo instante sua surpresa, e então ele disse: Biólogo? Cara, que surpresa boa. Acho que eu vou gostar de você. Venha, vamos entrar. Era por volta das 18:00 horas da noite e embaixo de uma frondosa árvore Mangueira dezenas de pessoas sentadas em cadeiras brancas de plástico se enfileiravam uma ao lado da outra, posicionadas diante de uma mesa também de plástico posta em frente a uma casa simples de paredes brancas, janela pequena e porta azul.

Entre os convidados, um engenheiro, morador da região que foi convidado para contestar que os moradores causavam impacto ao meio ambiente local, a advogada do ILOGU, para ser apresentada e para falar sobre a importância dos moradores se defenderem legalmente; e eu, representando a AMMA e a prefeitura de Goiânia, que estava lá certamente para explicar que impacto ambiental que eles estavam causando. Foi uma experiência embaraçosa, mas importante, pois, me sentia solidário a eles mesmo representando o poder público que quer retirá-los para a construção de uma via de tráfego rápido de veículos, a Marginal Botafogo.

Por outro lado, a oportunidade rapidamente agiu como um combustível para meu interesse em continuar a pesquisa. Durante o ano de 2014 voltei algumas vezes ao ILOGU para conversar com Jorge e Ozias, que buscavam em mim soluções da AMMA quanto à coleta precária de lixo na região e uma alternativa ambiental que os ajudasse a continuar em suas casas. Seus olhares ainda desconfiados e suas reivindicações ao órgão ambiental por melhoria estabelecia a posição que eu ocupava de agente da prefeitura de Goiânia.

Foi no ILOGU, em fevereiro de 2015 que expliquei para Jorge meu desejo de realizar com a comunidade um vídeo contando suas histórias e apresentando suas memórias. Falei pela primeira vez que esse vídeo ajudaria a escrever meu trabalho final no curso de mestrado e que poderia ajudar na luta da comunidade, já que se tornaria uma pesquisa acadêmica. Ele se interessou imediatamente pela proposta, e ressaltou que um estudo universitário poderia dar mais força ao grupo e atrair o olhar de professores e alunos para o conflito em que estavam envolvidos.

\footnotetext{
${ }^{3}$ Sou servidor público concursado no cargo de Analista em Obras e Urbanismo da prefeitura de Goiânia como biólogo, minha primeira graduação.
} 
Então Jorge e eu combinamos que eu levaria a câmera filmadora e ele me levaria nas casas dos moradores, faria as entrevistas, decidiria quem e onde filmar, e todos decidiriam quais histórias eram importantes para eles de serem contadas. Concordei em deixar que o ILOGU utilizasse todos os vídeos, disponibilizando as entrevistas na página virtual do instituto na internet ${ }^{4}$, nas reuniões com a comunidade e em audiências públicas. Além disso, combinei que eu não decidiria o roteiro ou editaria qualquer filme sozinho, que toda a edição das imagens, do som e o roteiro de um possível filme seriam elaborado coletivamente com o ILOGU.

As primeiras experiências não foram bem sucedidas. Sem recursos para comprar uma câmera filmadora, realizamos algumas filmagens com um iPad e um aparelho de telefone celular. Filmamos uma reunião e algumas entrevistas com moradores, mas os vídeos não ficaram com boa qualidade. Foi só no final do ano de 2015 que conseguimos junto ao PPGAS da $\mathrm{UFG}^{5}$ uma câmera filmadora para a realização dos vídeos com o ILOGU.

Nos primeiros meses de 2016 filmamos ruas, casas, pessoas e eu busquei participar das reuniões registrando ora o que Jorge me pedia para gravar e mostrar, ora o que meus olhos buscavam enxergar. No início o estranhamento, a câmera incomodava e causava um olhar sobressaltado nas pessoas que ainda me viam com desconforto. Introduzir a câmera nas reuniões e nos diálogos mais triviais levou um tempo para os moradores e para mim, mas aos poucos se tornou regular, normal até para se dar um sorriso, um "thauzinho", ou nem ligar para a câmera que com o passar do tempo estava sempre ligada, num processo de naturalização que por fim, acabou me aproximando deles nesse diálogo entre meu olhar, a câmera e os moradores.

Nesse lugar peculiar de pesquisador e planejador na cidade onde vivo e trabalho, foi pelo método antropológico que conforme esclarece Da Matta (2010), se pauta pela descoberta da coerência interna: vozes, gestos, reflexões, articulações e valores, de qualquer sociedade pelo pesquisador, dando-lhe um sentido pleno que a experiência de trabalho de campo em conjunto com as teorias aprendidas na universidade permitem teorizar que eu estive lá buscando entendê-los.

\footnotetext{
${ }^{4}$ www.ilogu.org.br

${ }^{5}$ Programa de Pós-Graduação em Antropologia Social da Universidade Federal de Goiás.
} 
Não devemos esquecer, reforça Velho (2013), que não se trata de um trabalho que interpreta dados brutos, "objetivos" e "naturais", mas uma interpretação da interpretação. O antropólogo tem como objeto de reflexão a maneira como culturas, sociedades e grupos sociais representam, organizam e classificam suas experiências, devendo captar a lógica que define a especificidade da experiência de um sistema cultural particular. O método, completa Da Matta (2010), obriga o pesquisador a entrar em um processo profundamente relativizador de todo o conjunto de crenças e valores que lhe é familiar.

É importante ressaltar que há algum tempo as Ciências Sociais têm se dedicado a estudar as políticas públicas, principalmente por lançar mão de dados qualitativos e pelo seu cuidado com a subjetividade dos atores envolvidos. Segundo Giddens (2009:02) "a subjetividade é o centro previamente constituído da experiência de cultura e história, e como tal fornece o fundamento básico das ciências sociais ou humanas". No caso da antropologia, seu olhar está voltado principalmente para as contradições, incompatibilidades e tensões que compõem as condições dinâmicas subjacentes à ordem social, bem como os diferentes atores participam e reagem à implantação dessas políticas (Miranda; Oliveira; Paes, 2007).

Em termos de posição epistemológica, a antropologia se caracteriza pelo relativismo, valorizando o discurso do nativo e preterindo quadros de interpretação e análise mais gerais e universalizantes; e a etnografia, seu método tradicional, é uma forma especial de operar em que o pesquisador entra em contato com o universo dos pesquisados compartilhando seus horizontes numa relação dialógica de troca, comparando suas próprias representações e teorias com as deles, para então refletir e partir para um modelo novo de entendimento, ou ao menos, partir para uma pista nova (Magnani, 2003, 2012).

O antropólogo permanece um tradutor por excelência, capaz de explicar valores sociais ou decifrar códigos simbólicos de sociedades buscando desvendar ideologias e representações numa perspectiva comparativa com sua própria ideologia-cultura de socialização. Seu objetivo é alcançar a estrutura inconsciente do espírito humano e descobrir na estruturação dos domínios culturais seus princípios mentais de elaboração (Rocha; Eckert, 2013).

Portanto, ao considerarmos a etnografia em relação às políticas públicas, observamos que a etnografia subverte a lógica normalmente presente, pois permite o 
enfoque na dimensão subjetiva das ações, deixada em segundo plano, ampliando o entendimento de como as regras de controle da ordem social são definidas pelos grupos, pela forma como expressam os conflitos e as maneiras pelas quais eles são administrados. Dessa forma, a etnografia e o olhar antropológico possibilitam o questionamento das práticas daqueles que são responsáveis pela implantação e execução das políticas públicas, assim como possibilitam a compreensão das conquistas e dos obstáculos que surgem a partir da intervenção do poder público (Miranda; Oliveira; Paes, 2007).

Já a política pública enquanto objeto de estudo é uma disciplina prática cujo propósito explícito é aconselhar os agentes públicos sobre a melhor maneira de lidar com os problemas públicos. Analisada por muitas abordagens, na perspectiva positivista privilegiou-se as ideias e técnicas derivadas da ciência econômica e baseou-se na noção de que se deve esperar que os indivíduos tomassem a maioria das decisões sociais por meio de mecanismos de mercado (Howlett; Ramesh; Perl, 2013).

Contudo, segundo os autores, no início da década de 1990, uma perspectiva póspositivista surgiu em resposta à insatisfação generalizada com a orientação tecnocrática que a disciplina havia tomado, com sua obsessão pelas análises quantitativas, separação objetiva entre os fatos e valores, e com suas conclusões generalizáveis; foi então que se laçou mão de reflexões subjetivas.

Além disso, com a crítica a respeito de políticas públicas burocráticas "de cima para baixo" que sufocam a democracia e a participação social, a vertente chamada póspositivista partiu do pressuposto de que não existe entendimento "objetivo" ou inquestionável único dos problemas e soluções políticas, tão pouco objetividade analítica e neutralidade política. Defendeu a necessidade de promover a democracia e a participação social no Estado Moderno, incluindo os cidadãos ordinários no processo político, e a remoção da desigualdade entre os participantes (Howlett; Ramesh; Perl, 2013).

$\mathrm{Na}$ Ocupação do Jardim Botânico, o trabalho de campo buscou a intersubjetividade lançando mão de imagens e de vídeos. Inspirado nas experiências dos Vídeos nas Aldeias que começaram em 1986 quando os pesquisadores apresentaram o material filmado aos índios Nambiquara e causaram uma mobilização coletiva que chamou atenção e que acabou sendo levada para outros grupos (Araújo, 2012). 
Segundo Araújo (2012), por meio de oficinas, os indígenas aprenderam a manusear a máquina e se tornaram cineastas que narram em primeira pessoa suas experiências junto com depoimentos de membros da comunidade produzindo mais vídeos que mostram como cada povo incorpora o vídeo de maneira particular.

A produção audiovisual em Antropologia se ampliou na passagem do século XX para o século XXI tornando os recursos audiovisuais instrumento de diálogo vigoroso nas experiências etnográficas, propiciando aos grupos sociais estudados compartilhar as experiências de construção de imagens de si e ampliando na produção antropológica sua eficácia simbólica na construção de memórias coletivas em comparação com a cultura de escrita que orienta os meios acadêmicos. A memória coletiva é tecida pelo fenômeno da intersubjetividade sob o plano da cultura humana e de suas obras, é um recital de imagens que resiste à ação corrosiva do tempo, parte integrante da consciência poética da humanidade sobre seu destino mortal (Rocha; Eckert, 2013).

Inspirado também pelos princípios rouchianos na realização de uma antropologia compartilhada a partir da filmagem participante, da edição compartilhada e da publicação do material monográfico e audiovisual. A câmera participante é a dinâmica de apresentar ao grupo o material registrado durante o trabalho de campo. Essa prática favorece o diálogo, e a comunidade, como sujeito coletivo, dialoga sobre o que deve ser filmado, quem deve ser filmado, como, quando e onde (Alvarez, 2013).

Nesse diálogo o antropólogo pode favorecer a dimensão dialógica, propiciando uma direção também compartilhada. A edição compartilhada, por sua vez, diz respeito à participação do grupo na elaboração do roteiro, da captação e da montagem do vídeo. Dessa maneira o grupo se apropria tanto do vídeo para construir sua própria imagem quanto do rumo da pesquisa (Alvarez, 2013).

Ademais, a produção do vídeo etnográfico favorece o estudo dos arranjos interpretativos dos habitantes, que conforme Rocha e Eckert (2013:13), “orienta as formas representacionais do patrimônio e da memória da comunidade urbana local investindo-se na compreensão das experiências vividas dos seus significados culturais, disponíveis social e historicamente".

É importante ressaltar que o uso das imagens no início da pesquisa tinha como objetivos principais estimular o debate entre os moradores por meio dos registros visuais 
e retratar os bairros da região, para que após todas as intervenções propostas pela prefeitura, as imagens pudessem ser um registro da memória das pessoas que moram naquela região. Contudo, conforme a pesquisa foi se desenrolando, os vídeos produzidos em parceria com os moradores ganharam destaque na pesquisa e passaram a serem observados como sugere Achutti (1997), como textos, afirmações e interpretações sobre o real.

Ressalta-se também que o método da câmera compartilhada foi adaptado à dinâmica do grupo. Primeiramente nas entrevistas, quando Jorge me levava na casa dos moradores, nós nos posicionávamos em frente a eles com a câmera no tripé e fazíamos as perguntas. Nas primeiras entrevistas Jorge se sentiu pouco à vontade em perguntar, mas com o tempo fazia a maior parte das perguntas, parecia um repórter; caminhava com os moradores que nos apresentavam suas casas, e eu os seguia com a câmera filmadora.

A câmera também foi usada nas reuniões, momento de diálogos entre os moradores e com a participação da prefeitura. Nesses casos, a câmera ficava comigo, pois os moradores e o Jorge estavam envolvidos nas discussões do ILOGU, o que me proporcionou condições de circular entre eles e entre os representantes da prefeitura. Sempre que eu era questionado por um dos lados o que eu fazia ali, eu sempre dava a mesma resposta, "estou fazendo uma pesquisa de mestrado, retratando o diálogo dos moradores com a prefeitura sobre o processo de desapropriação e a proposta de uma Operação Urbana Consorciada".

Em festas, houve momentos que levei uma câmera fotográfica que foi usada por outras pessoas, como a filha de Jorge, por exemplo, que, segundo ela mesma, adorou a experiência de ser fotógrafa. Os vídeos atualmente têm sido apresentados aos moradores nos eventos organizados pelo instituto. Jorge tem manifestado o interesse de fazer um documentário com o material e junto com outros moradores já editaram pequenos vídeos.

Esses vídeos têm sido usados pelo ILOGU para sensibilizar os atores envolvidos e para desconstruir a ideia de que a ocupação é violenta, sem história e sem memória. As gravações já foram apresentadas em reuniões buscando a união dos vizinhos dentro do próprio grupo que busca conciliar múltiplos interesses e identidades, e já foram apresentadas em eventos e festas no instituto. 
Outro aspecto epistemológico do método também se destaca, os vídeos deixam de ser meros retratos de indivíduos e lugares, e passaram a servir também como caderneta de campo virtual e são, sempre que necessário, revistos em busca de pistas e novos entendimentos sobre o conflito, que, sobretudo, tem mostrado pessoas se mobilizando para defender suas casas e suas histórias naquele lugar; mostrado suas alegrias e tristezas acerca da vizinhança, das relações sociais, das relações com o poder público e de seus hábitos cotidianos (Linfield, 2012).

Como agente da prefeitura, o conhecimento dessas memórias e o relato dessas histórias têm servido de argumento para debates nos Conselhos de Habitação e de Políticas Urbanas, onde tenho sido conselheiro, assim como no órgão ambiental onde trabalho. Embora ainda sejam muitas vezes vistas com resistência sob um discurso de que são muito "academicistas" e muito distantes da realidade, essas reflexões têm provocado debates e têm, quem sabe, reificado a luta dessas pessoas nas reuniões desses Conselhos, onde agora querem uma vaga para o ILOGU como entidade social, com direito a voz e voto.

Ademais, o estudo de uma metrópole como Goiânia é um desafio para qualquer campo de pesquisa. Para a antropologia se destaca o que (Magnani, 2012:251) chamou de "a tentação da aldeia", a tentativa de buscar um suposto lugar ideal para aplicar o método etnográfico no contexto diversificado, heterogêneo e interconectado das metrópoles. Contudo, nesse ambíguo lugar de fala em que me encontro, a antropologia favorece a compreensão do fenômeno urbano, principalmente para a pesquisa da dinâmica cultural e das formas de sociabilidade nas grandes cidades contemporâneas.

Portanto, a relevância do método qualitativo e a consideração de elementos subjetivos para essa pesquisa derivam do fato de considerar o ambiente, sobretudo as cidades, um ecossistema e uma construção social percebida pelo olhar e pelos valores de quem o vê, tornando indissociáveis os aspectos objetivos e subjetivos. Ao contrário de se considerar a neutralidade dos atores envolvidos, buscou-se então captar suas influências, inspirações, posições políticas e formações para podermos entender as forças que estão presente na agenda de elaboração dessa política pública (Laperrière, 2008). 


\section{Ocupação, as Casas e as Vidas em Construção}

A cidade de Goiânia foi fundada para ser em $1937^{6}$ a nova capital e sede administrativa do Estado de Goiás, em substituição à Cidade de Goiás, antiga Vila Boa de Goiás. Buscava representar não só a modernidade da época, como as ambições de urbanização e aumento da produção agrícola do país, já contava com 1.302.001 habitantes segundo o último censo realizado, o de 2010 pelo IBGE, Instituto Brasileiro de Geografia e Estatística. Fundada após a Revolução de 1930, foi anunciada pela mídia da época como a manifestação prática da conquista do Brasil pelo Brasil, um movimento profundo de nacionalidade proporcionado pela Marcha para o Oeste ${ }^{7}$ (Machado, 2007).

À época da inauguração, para Colemar Natal e Silva, advogado que fez parte da equipe nomeada pelo então Interventor Federal do Estado, Pedro Ludovico Teixeira, para a escolha do local da construção de Goiânia, a nova capital tinha três faces, a do passado, que representava as lutas e conquistas, a do presente, marcada pela surpreendente concretização do plano; e a do futuro:

a vertigem do porvir; Goiânia aparece então, diante da comunidade brasileira, ao mesmo tempo como a síntese de todas as conquistas e glórias do passado, bem assim a previsão arrojada, sábia e científica do futuro, tendo ainda o imperativo indeclinável de representar a consciência da realidade contemporânea (Natal e Silva, 1993:07).

\footnotetext{
624 de outubro de 1933, data comemorada como de aniversário de Goiânia, foi a data de lançamento da pedra fundamental por Pedro Ludovico Teixeira, porém a efetiva transferência da capital só ocorreu em 1937 através do Decreto Estadual N. 1816.

${ }^{7}$ Fundada três anos após a Revolução de 30, a cidade de Goiânia foi planejada sob influência da Marcha para o Oeste, política desenvolvida pelo governo Vargas para estimular a ocupação branca e exploração das riquezas naturais do Centro Oeste brasileiro.
} 


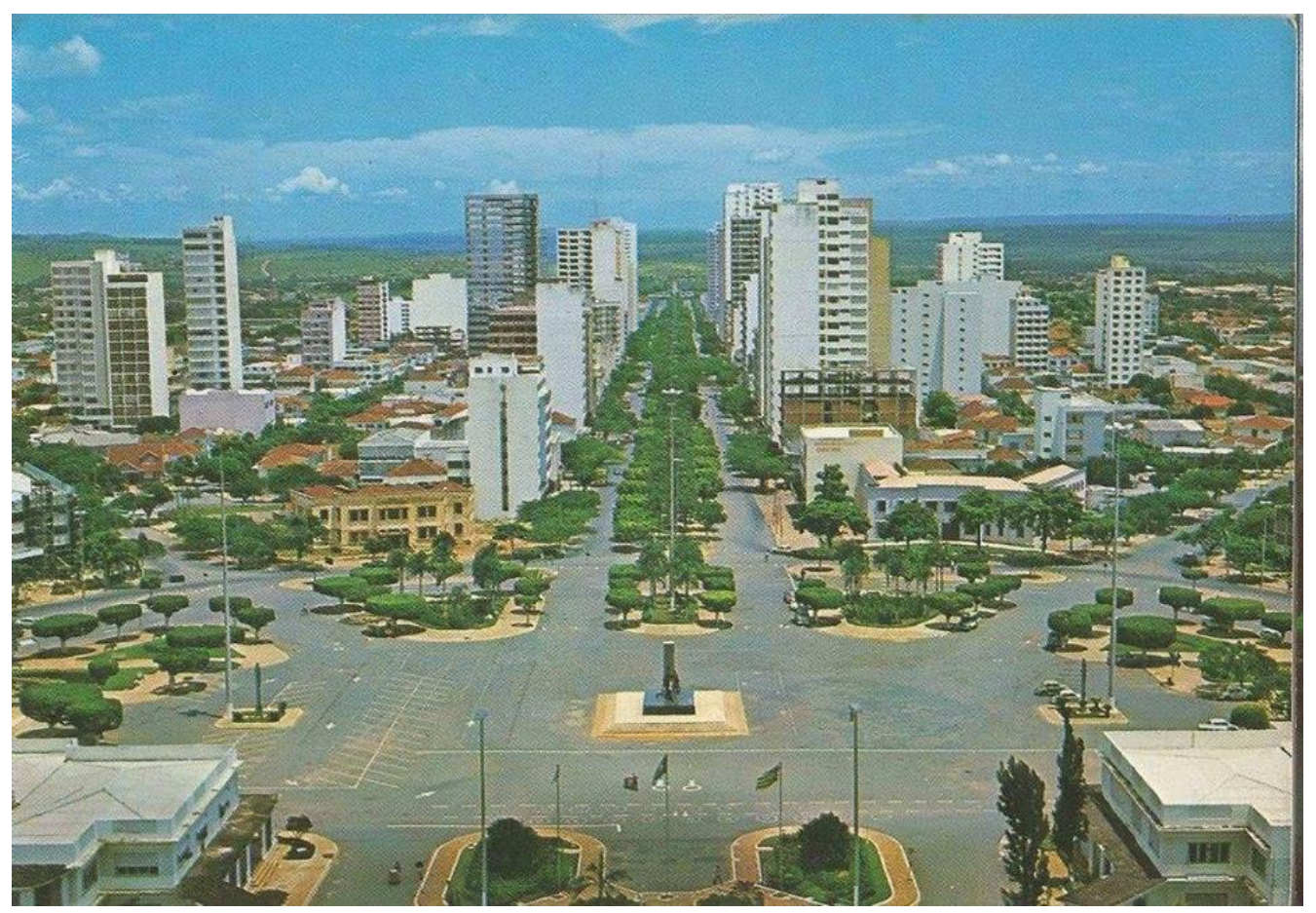

Figura 6: Foto do bairro Setor Central de Goiânia na década de 1970, com destaque para a Praça Cívica no início da Avenida Goiás e a Estação Ferroviária no seu final. Foto de autor desconhecido.

Além de ser a capital mais próxima à Brasília, a capital federal, Goiânia está no rol das cidades que tiveram suas construções planejadas em pleno século XX, à luz de um forte ideal de progresso, e pode-se dizer que serviu como "ensaio" para a construção da capital federal cerca de vinte anos depois. Representou à época o desafio de se planejar uma cidade modernista com conceitos da arquitetura vigente no meio do Planalto Central brasileiro, uma paisagem que aos olhos de um projetista estrangeiro, não nativo, parecia certamente, o meio do nada.

Representou também a substituição da política "Coronelista” dos Caiados, família local que dominava desde 1912, pela oligarquia de outra família, os Bulhões, apoiada pelo então Interventor Federal, Pedro Ludovico Teixeira. A Revolução de 1930 prenunciava, para o Brasil e para Goiás, novos tempos, por isso nada melhor que uma nova capital para se instaurar uma nova era política no Estado (Machado, 2007).

Para os moradores da antiga capital, a Cidade de Goiás,

A transferência da capital gerou inúmeras rupturas, tanto materiais, quanto afetivas e simbólicas. Os vilaboenses assistiram atônitos e amedrontados transformações cruciais na ordem social ali estabelecida. Razões práticas e simbólicas dos vilaboenses foram desconsideradas e destruídas em nome do projeto da nova capital (Tamaso, 2007:98). 
Durante o processo de mudança do centro político entre 1933 e 1942, os moradores da antiga capital se viram espoliados cotidianamente com a transferência gradativa dos serviços públicos para a nova capital. O Hospital, O Grupo Escolar, as Faculdades de Direito e Farmácia, a Escola Técnica, os Correios e etc, que foram acompanhados obrigatoriamente pelos servidores públicos, separando famílias e impactando a organização social (Tamaso, 2007).

A ideia da mudança da capital se apresentava como uma "estratégia", uma necessidade do capitalismo e da dinamização da economia goiana, incorporando-a cada vez mais à economia nacional, e se justificou objetivamente devido aos avanços das técnicas urbanísticas da época que exigia uma cidade planejada. Para Atílio Correia Lima e Armando de Godói, responsáveis pelo projeto da capital:

a cidade moderna, quando lhe proporciona todos os elementos de vida ao seu estabelecimento e a sua expansão se prende a um plano racional, isto é, que obedeça às determinações do urbanismo - é centro de cultura, de ordem, de trabalho e de atividades bem coordenadas (Natal e Silva, 1993:07).

Após a publicação do Decreto $\mathrm{N}^{\circ} 2.737$ de 20 de dezembro de 1932 nomeando os integrantes da comissão responsável pela escolha da capital, o primeiro ato foi realizado em janeiro de 1933 às 21:00 horas no salão nobre da prefeitura municipal de Bonfin, quando Colemar Natal e Silva, então secretário da comissão ponderou:

\begin{abstract}
Assim que é, na impossibilidade de percorrer todo o estado à procura de localidade e mesmo na contingência de atender a numerosos pedidos de visitas a localidades sulinas, achava que a Comissão conhecedora das graves dificuldades e embaraços que a falta de transporte acarreta, devia assentar, como dogma para diretrizes de seus trabalhos, o critério da proximidade da estrada de ferro e não escolha dela muito afastado, devendo os estudos abranger as localidades de Bonfin, Ubatã e Campininhas. Achava que também outros postulados básicos deviam, de início, ser fixados para o critério da escolha, assim uma vez próxima à via férrea, deveria a localidade a ser escolhida dispor de três requisitos essenciais: abundância de água, bom clima, e topografia adequada, analisados os demais requisitos também criteriosa e conscienciosamente para uma feliz conclusão (Natal e Silva, 1993:13)
\end{abstract}

A região escolhida para a construção era composta em sua maior parte por fazendas, sendo Campinas a cidade mais próxima, hoje bairro da capital. Porém, o local foi escolhido pela sua proximidade com a estrada de ferro, por possuir água em abundância, topografia predominantemente plana, clima agradável e estar localizado no centro do Estado e do país (Ribeiro, 2010). A autora destaca que a cidade se iniciou às margens do Córrego Botafogo, nas proximidades do eixo da estrada que lhe dava acesso 
inspirada pelos princípios vanguardistas da Europa e dos Estados Unidos trazidos pelo urbanista brasileiro formado em Paris, Atílio Correia Lima.

O dinheiro para construir a cidade veio de duas maneiras: empréstimos junto ao Governo Federal, que tinha a construção da capital como parte de um projeto expansionista do governo do então presidente Getúlio Vargas; e da venda dos lotes, que dava forma a nova cidade e movimentava o mercado local. Ademais, foi preciso políticas que estimulassem a emigração para suprir a necessidade de mão de obra, como auxílio financeiro para os operários, e propaganda em todo o estado, além de suspensão dos impostos para exportação de produtos e para a instalação de indústrias (Chaul, 1999).

Muito embora fundamentais para a realização do sonho da capital moderna, os operários que vieram principalmente do interior do estado de Goiás, de Minas Gerais e de estados do nordeste brasileiro, serviram ao processo de mais-valia trabalhando com salários desvalorizados e mantidos em um regime de "vales" ${ }^{8}$ que serviam para mantêlos presos na obra, erguendo uma cidade planejada que já nascia com suas primeiras ocupações irregulares e injustiças sociais (Chaul, 1999).

Muitos operários e emigrantes, sem alternativa para morar, ocuparam as margens dos cursos d'água da cidade, negligenciados pelo poder público. "Tática" semelhante foi observada em Belo Horizonte, cidade planejada e criada em 1895, que dois anos antes de ser inaugurada já contava com duas ocupações irregulares compostas por operários e emigrantes. Brasília em seguida também foi construída sem prever um local para os trabalhadores morarem. No caso da capital federal, após o início da construção foi proposto o Núcleo Bandeirante, então chamado de Cidade Livre, assentamento provisório para abrigar os operários que tinha a data de inauguração da capital como data marcada para ser erradicado (Pasternak, 2016).

Em Goiânia, como em outras cidades planejadas para serem grandes capitais, as ocupações irregulares nasceram com a cidade não para serem "trampolins" para obtenção de moradia na malha urbana formal, mas sim como a única opção para moradia em uma estrutura social que não planejou a integração dos operários, dos emigrantes pobres e suas famílias.

\footnotetext{
${ }^{8}$ Adiantamentos em dinheiro emitidos pelo patrão ao funcionário antes do dia de pagamento pactuado entre os dois, e que, portanto, deve ser descontado no pagamento.
} 
Para Magnani (2003), grandes aglomerados urbanos em contraposição à zona rural e às pequenas cidades interioranas são vistos como lugar de realização de um projeto de vida por meio da possibilidade de emprego estável, da aquisição da casa própria, do acesso à escola e aos serviços de saúde. Contudo, entre o que se espera da cidade e o que realmente ela oferece, há uma distância que é percebida não apenas sob a forma de carências, mas também pela distribuição desigual dos recursos e equipamentos públicos.

Durante o crescimento da cidade nos anos seguintes, os corredores naturais em volta dos cursos d'água acabaram esquecidos pelo planejamento urbano e serviram para o assentamento de muitos dos construtores anônimos da cidade, que marginalizados acabaram cerceados de seu progresso, mas que encontraram nesses lugares, áreas com riquezas naturais fundamentais como a água e que embora não tivesse saneamento básico, eletricidade, água tratada e ruas, estavam temporariamente "livres" para serem ocupadas.

A Ocupação do Jardim Botânico foi uma das muitas localizadas às margens do Córrego Botafogo que abrigou essas pessoas, conforme relata Professor Pedro Wilson,

\begin{abstract}
Goiânia tinha o setor Central e a divisa era o Córrego Botafogo. Então na margem do Botafogo desde sua confluência com o Córrego Anicuns e o Rio Meia Ponte na região Norte de Goiânia: Criméia, Emílio Póvoa, Capimpuba, Nova Vila, Vila Nova, Setor Universitário e Jardim Goiás, na margem direita do Botafogo e em algumas na margem esquerda, foram áreas de ocupação feita pelo pessoal que trabalhava.
\end{abstract}

A disponibilidade de água foi um fator determinante para o assentamento das pessoas. Durante a ocupação da região a água foi decisiva para se escolher morar às margens do córrego, local com risco de inundação, habitat de insetos e outros animais, mas fonte de água limpa para a alimentação, para a limpeza e para matar a sede, ou por outro lado, para os que não encontravam lugar perto do córrego restavam os terrenos mais a cima onde era preciso pagar para furar cisternas para ter água.

Dona Maria do Bar da Mata relata (Figura 7):

Olha, eu estou aqui há 58 anos, vai fazer esse ano (...) eu vim para essa berada de córrego porque eu tinha cinco filhos e não tinha dinheiro para furar uma cisterna, por isso eu vim para cá (...). Aqui enfrentei cobra, enfrentei cascavel, vaca, cavalo, porco, tudo que o pessoal soltava ai para ver se acabava com a gente aqui, mas Deus é mais (...). Lá em cima era pior antes porque tinha que furar cisterna, aqui em baixo era uma maravilha, água limpinha, tinha uma bica d'água linda. 


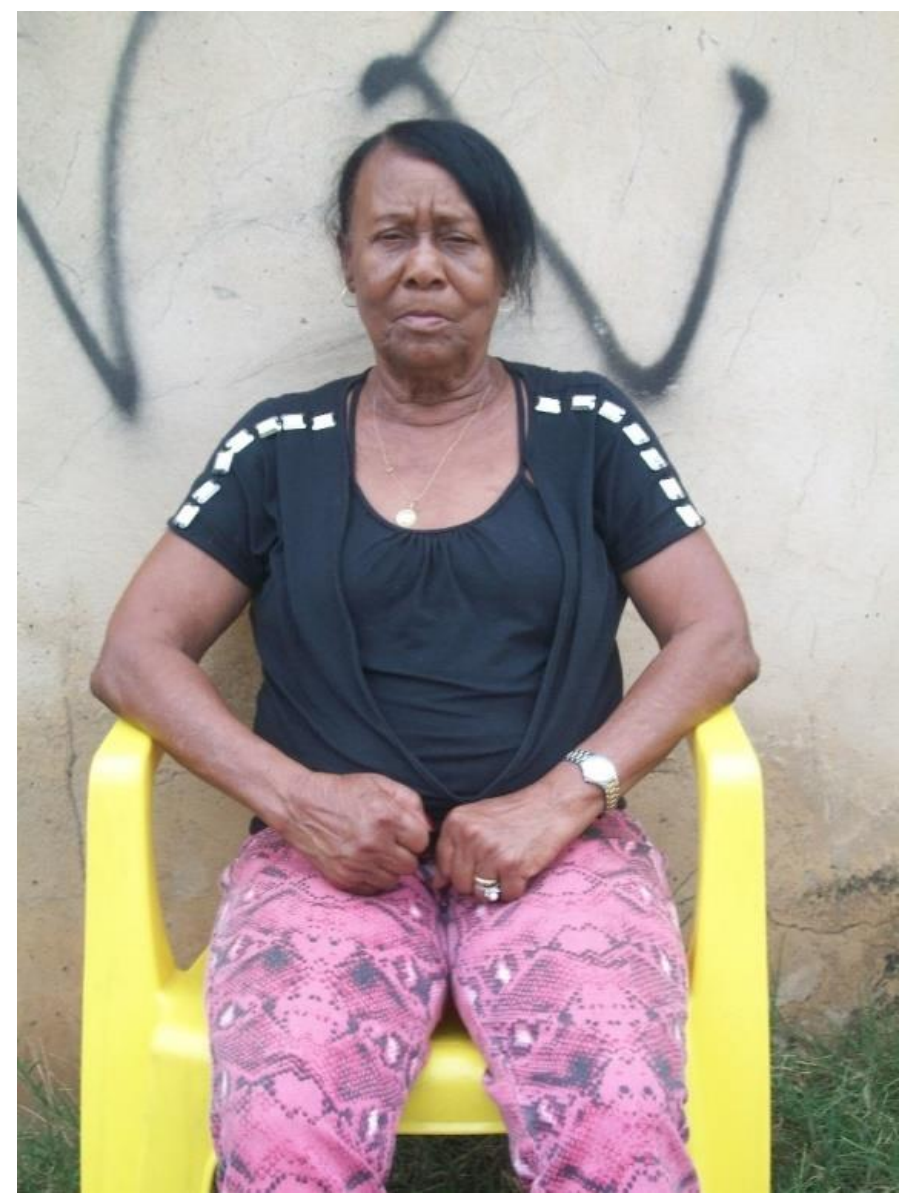

Figura 7: Dona Maria do Bar da Mata. Foto do autor.

Outra senhora conhecida pelo mesmo nome, Dona Maria reforça: Já tem muito tempo quando eu mudei para cá, a gente chegava na porta aqui fora, não tinha nenhuma casa aqui, só era mato, eu lavava roupa lá no córrego (...) porque não tinha cisterna aqui, não tinha água. A água foi um dos elementos decisivos na ocupação da cidade, e naquela região, elemento fundamental para a subexistência. Ademais, influenciou na geografia, na arquitetura e nos hábitos dos moradores.

Senhor Mário relembra quando chegou, após ter comprado um lote com a ajuda do patrão que lhe emprestou o dinheiro e descontou de seu salário ao longo dos anos:

Eu vim aqui com a foice, rocei, abri e construí três cômodos. Nós moramos aqui uns seis meses um ano no chão batido, no chão mesmo, eu, minha esposa e minhas duas filhas. Eu trabalhava e não tinha tempo pra nada, aí no fim de semana eu fui arrumando. Ficamos sem luz, sem água quase um ano, não tinha luz, eu não tinha colocado luz aqui, não tinha água, eu furei uma cisterna e a gente usava o sarilho, não tinha energia. 
Os longos anos sem o fornecimento de água tratada pelo município são recordados pelos moradores ao narrarem suas experiências naquele lugar. As mulheres mais velhas entrevistadas lembram constantemente do tempo em que se lavava roupa no córrego. Como era um hábito comum, as casas procuraram se instalar com os fundos e as lavanderias voltadas para o córrego, assim utilizando ele como fonte de água para alimentação, para a limpeza e para beber, mas também utilizando ele para lavar roupa e para despejar o esgoto doméstico, canalizado diretamente para as águas do Botafogo. Hoje em dia é fácil observar que muitas casas ainda possuem os tanques de lavar roupas voltados para o córrego.

O mesmo ocorre com muitas casas que não estão às margens do córrego, essas casas normalmente são ligadas por algum caminho ao Botafogo e à mata. Quando entramos nelas é muito comum o primeiro cômodo ser a lavanderia, de alguma forma, ainda voltada para o córrego. Esse planejamento baseado nas condições disponíveis e da adaptação desses moradores com a dinâmica da mata do Jardim Botânico e do Córrego Botafogo é fruto de relações sociais e culturais inscritas nesse "lugar antropológico", cuja análise faz sentido porque foi investido de sentido pelas pessoas e em cada reiteração trivial conforta-os e confirma sua necessidade, e que é para Augé (2010:51),

aquela construção concreta e simbólica do espaço que não poderia dar conta, somente por ela, das vicissitudes e contradições da vida social, mas a qual se referem todos aqueles a quem ela designa um lugar, por mais humilde e modesto que seja.

As pessoas com faixa etária entre 30 e 40 anos se lembram do córrego de outra maneira, um lugar para as brincadeiras, onde viram os mais velhos cultivarem suas hortas e onde se podia pescar sempre que quisesse. Paula, com 33 anos, sempre morou na região e lembra assim de quando era criança:

Eu me lembro quando... Eu acho que ainda tem uns pés de Buriti ali embaixo e a gente conseguia chegar pertinho deles, ver o córrego lá embaixo. Na época o córrego era estreitinho, e a gente fazia guerrinha com os meninos do Setor Pedro. Era cheio de horta lá embaixo nessa época onde morava a comadre Fia, tinha as hortas e tinhas as minas d'água.

As casas que começaram como barracos de lona aos poucos se transformaram em barracos de alvenaria, poucas com os lotes cercados. Mas com o adensamento populacional da ocupação, segundo os moradores, iniciaram-se pequenos furtos, como os de bomba d'água que os obrigaram a construir muros em volta de suas casas. No mês de agosto os moradores passavam sufoco relembra com suspiro Paula. Por ser um período 
seco no estado de Goiás, o mês de agosto era marcado por cisternas vazias e falta d'água. Paula lembra: você puxava os baldes e eles vinham cheios de lama em agosto, era muito difícil.

O fornecimento de água tratada para a região começou só na década de 1990 com a instalação de uma rede de abastecimento. Hoje com o acesso à água tratada nessas casas, o córrego ficou mesmo para a disposição do esgoto doméstico. Sem saneamento básico, as famílias normalmente lançam seu esgoto no córrego, que atualmente é canalizado e tem seu leito impermeabilizado em quase todo perímetro urbano. Dona Natalina reclama: O que falta é saneamento básico, que é cobrado da gente, mas não tem esgoto, vem no talão de água, mas não tem esgoto (...), hoje está na parede do córrego.

Para Dona Neusa, que já mora com seu marido no local há 43 anos em uma casa um quarteirão acima do córrego, quando chove a água revela outro drama urbano de Goiânia, a ineficiência da rede de drenagem de águas pluviais:

Aqui tem muita coisa pra melhorar porque essa rua aqui quando chove a água vem aqui em cima, vira um rio aqui na porta, inclusive o Claudinho falou para mim uma vez que se eu arrumasse as pessoas para por a canalização, podia pôr dentro do quintal dele, mas eu acho que seria benefício das pessoas de baixo querer fazer, né?

Dona Neusa se refere à casa do seu vizinho da frente, que atravessando a rua está entre a casa dela e o córrego.

A sensação de mudança de um lugar é percebida pela experiência ao longo do tempo. Quando os muros chegaram à ocupação, ocorreu uma transformação nas relações sociais e na maneira como as pessoas se relacionam com as casas. Em algumas entrevistas foi lembrado que por muitos anos, as pessoas se deslocavam de uma casa para a outra pelos quintais, conversavam das janelas de suas casas. Um vizinho tinha liberdade para entrar no quintal do outro apenas passando pela cerca de arame, quando ela existia, e continuar seguindo os "trieiros", passarelas de terra onde o mato pisoteado morria formando verdadeiras vias feitas pelos moradores que atravessavam os quintais de várias casas, "táticas" de uso da cidade.

Hoje existem poucos trieiros, e os que existem hoje, a maioria está cimentado. Eles foram sumindo conforme os muros foram erguidos e a sensação de insegurança foi crescendo, mas a conformação de alguns conjuntos de casas, lotes com várias casas familiares uma ao lado da outra, que são ligadas por corredores sinuosos sugerem terem 
surgido ao longo dos anos, dos antigos trieiros que ligavam as casas das pessoas ao córrego e à mata.

Alguns exemplos ilustram mais as casas e as vidas dos moradores juntas em transformação, como o caso de Dona Sueli (Figura 8), mulher de pele branca e cabelos castanhos levemente ondulados abaixo dos ombros, muito simpática e que nos mostrou as casas no terreno que foi um dia todo de seu pai, mas que agora pertence a muitas famílias. Nessas casas hoje moram membros de sua família e de outras famílias que chegaram com o tempo e que hoje compartilham o mesmo terreno.

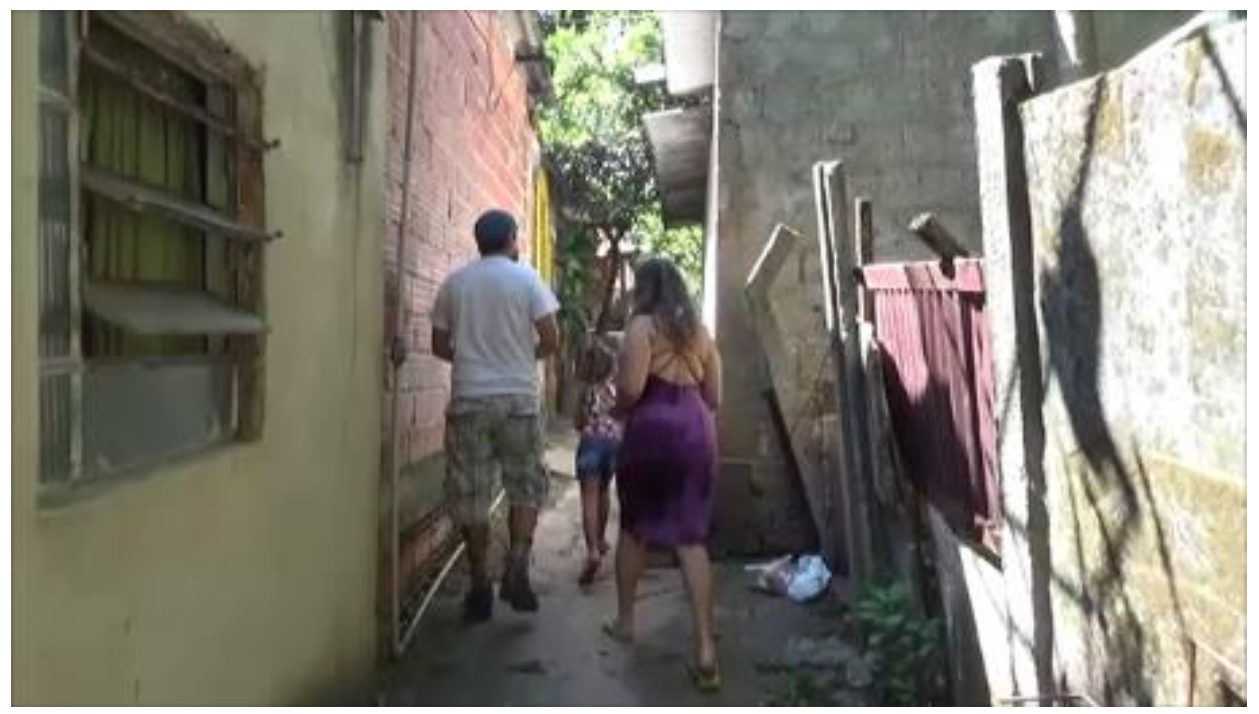

Figura 8: Conjunto de casas que foram construídas ao longo desse sinuoso caminho cimentado. Foto do autor.

Para Segura (2013:67),

El habitar, entonces, remite tanto a la relación de lós actores com el entorno como a las relaciones entre actores sociales em el entorno. Solo reponiendo la trama de relaciones de la periferia urbana y la temporalidad del habitar es posible comprender las variaciones em la significación de un lugar que es visto externamente como homogéneo.

As memórias de Sueli relembram o processo de crescimento desse conjunto de casas e de alguma maneira, dá pistas sobre as "táticas" de planejamento, formação e conformação de muitos lugares da ocupação que são semelhantes. A entrada da casa é estreita, um muro pequeno de aproximadamente 5 metros de extensão, com uma fina camada de reboco. Tem do lado direito o número $828 \mathrm{~B}$ pinchado em uma pequena parte cimentada e pintada de branco, logo acima de quatro caixas com hidrômetros. Do lado esquerdo, apenas uma caixa de cartas para os Correios. 
Duas colunas de metal fazem a sustentação do trilho do portão grande, também de metal pintado de cinza. Ao lado dele existe um pequeno portão que se abre para um longo corredor com um pouco mais de um metro de largura e que termina após a primeira casa, onde junto com o corredor que sai dessa casa, forma um grande e sinuoso trieiro cimentado até o córrego por onde as famílias foram se instalando e as casas foram construídas.

\begin{abstract}
Meu nome é Sueli Mendanha e já tem mais de 15 anos que eu moro aqui. Morava com a minha mãe, aí meu pai deu um pedacinho aqui pra gente morar. Meu pai tem 22 anos que ele faleceu. Minha mãe hoje tem 75 anos e mora ali com minha irmã, ela teve AVC e é aposentada do Estado. Aqui mora só família. Minha mãe na época alugava um barracão para o pessoal, mas como muitos não tiveram condições de pagar um teto, minha mãe dava um pedacinho para eles morarem, ficava com dó. Minha mãe chegou até a vender para umas duas famílias baratinho, para poder ajudar eles, né? Mas que a gente mora aqui tem mais de 30 anos. Quando meu pai comprou aqui, naquela época era assim: pagou comprou, não tinha escritura e nenhum recibinho.
\end{abstract}

Ao passar o portão, à direita um longo muro desce junto com o terreno, com aproximadamente 2 metros de altura. É rebocado até a metade, dando sinal de que foi aumentado posteriormente. $\mathrm{Na}$ frente, um pátio cimentado serve como estacionamento sobre a sombra de uma majestosa árvore Amendoeira que termina em uma casa. Sueli lembra que no início esse local possuía um buracão que foi aterrado, provavelmente um processo erosivo. Contudo, a área está embaixo de uma potente linha de transmissão de energia e tem limitação de uso, não podendo ser edificado residências embaixo dela.

Do portão, a visão que se tem dá poucos sinais da profundidade e da diversidade que aquele terreno possui. Podemos ver da esquerda para a direita, uma pequena garagem coberta para um carro, duas janelas de metal, oito caixas do serviço de energia elétrica e uma pequena varanda. Parte da casa é pintada de branco e outra de azul, sendo o azul mais recente. Os telhados da casa, que do portão deve estar há uns 20 metros, podem ser vistos na altura dos olhos por causa do acentuado aclive do terreno, é metade de telha de barro e outra metade, de telha plana de amianto.

Então ela conclui:

Quando meu pai comprou aqui era só mato, aí logo Seu Sérgio também comprou ali. A gente vai lutar pelo direito da gente, porque a gente tem direito aqui. Tem sim, por isso que a gente tem que reunir todo mundo e batalhar por isso, e as autoridades tem que ver o nosso lado também, e se nós não tivéssemos aqui? Estariam outras famílias.

Sueli nos apresenta cada construção de um conjunto de nove (9) casas que foram construídas até as margens do córrego em um único lote por um caminho sinuoso, 
provavelmente fruto do deslocamento dessas pessoas há muitos anos, ao longo dos antigos trieiros, agora cimentados. Construções que se confundem em suas memórias com suas próprias vidas, e a vida de suas famílias.

"Aqui cada um tem seu direito, meus irmãos moram aqui. Essa aqui é minha casa, mora eu e meu filho aqui, mais na frente mora meu irmão, depois mora a outra irmã minha com minha mãe", apontando com o dedo para todos os lados do conjunto de casas, e continuou falando:

Meu pai construiu aqui, era só um cômodo quando nós mudamos, aqui era cheio de mato. Eram cinco pessoas na família em um cômodo só. Aí meu pai foi aumentando os cômodos aos poucos, então nós batalhamos aqui, nós sofremos aqui. Minha mãe vinha para cá no começo com medo de alguém invadir aqui quando nós compramos.

$\mathrm{Na}$ varanda da primeira casa é possível ver algumas cadeiras de plástico, uma mesa de plástico e uma cadeira de balanço, é a casa de Sueli. Na frente uma porta dá acesso a uma espécie de alpendre com lavanderia, que ao em vez de janela, possui uma grande grade do teto até a metade da parede para aproveitar melhor o sol e a iluminação natural. Colada à casa de Sueli está a casa de seu irmão, a segunda casa, que fica à esquerda de onde os corredores se juntam e forma um único trieiro que em sua maior parte deve ter menos de 2 metros de largura, sendo em alguns lugares mais largo e em outros mais estreito.

A casa tem uma entrada estreita, também com a lavanderia na entrada, tem na frente uma grande grade em substituição à janela que permite maior entrada da luz do sol para dentro da casa. É na frente dessa casa que também está o final do corredor que se inicia na calçada da rua lá em cima. Sobre nossas cabeças, o varal repleto de roupas faz composição com a variedade de cores, texturas, paredes, azulejos, muros e grades que margeiam o trieiro. A terceira casa é a da mãe de Sueli e fica à esquerda, também com grades e lavanderia na frente, finalizando o núcleo inicial da família construído pelo próprio pai, núcleo esse que se iniciou com um cômodo e uma família de cinco pessoas.

Então Sueli nos leva trieiro abaixo: “A energia nós puxamos, era um relógio só para todo mundo, para os aluguéis tudinho e aí nós dividíamos, aí depois é que nós conseguimos por um relógio para cada um deles".

O trieiro que é cimentado até a última casa, que já está há menos de cinco metros do córrego, é um caminho que possui curvas para todos os lados e nos enche de 
curiosidade. Expõem ao longo de sua extensão, canos de vários diâmetros que surgem das paredes indo para várias direções, árvores e plantas por todos os lados, plantadas durante o longo processo de ocupação, postes metálicos que levam energia para todas as casas ou que sustentam caixas d'água. O trieiro é usado por pedestres, ciclistas e por motociclistas, que disputam o mesmo espaço (Figura 9).

No rodapé dos muros os musgos e algumas gramíneas se desenvolvem até a altura da marca da água que escorre da enxurrada pelo trieiro e desce até o córrego. Segundo Sueli: "Quando chove a enxurrada passa aqui quase levando tudo, desce aqui que faz até dó, se tiver alguém aqui é levado”. Se olhar para o céu, o teto do trieiro é feito pelo encontro dos telhados das casas dos dois lados em contraste com as copas de árvores que crescem nos quintais, nos muros e na mata, além das torres metálicas que sustentam as caixas d'água aqui e acolá.

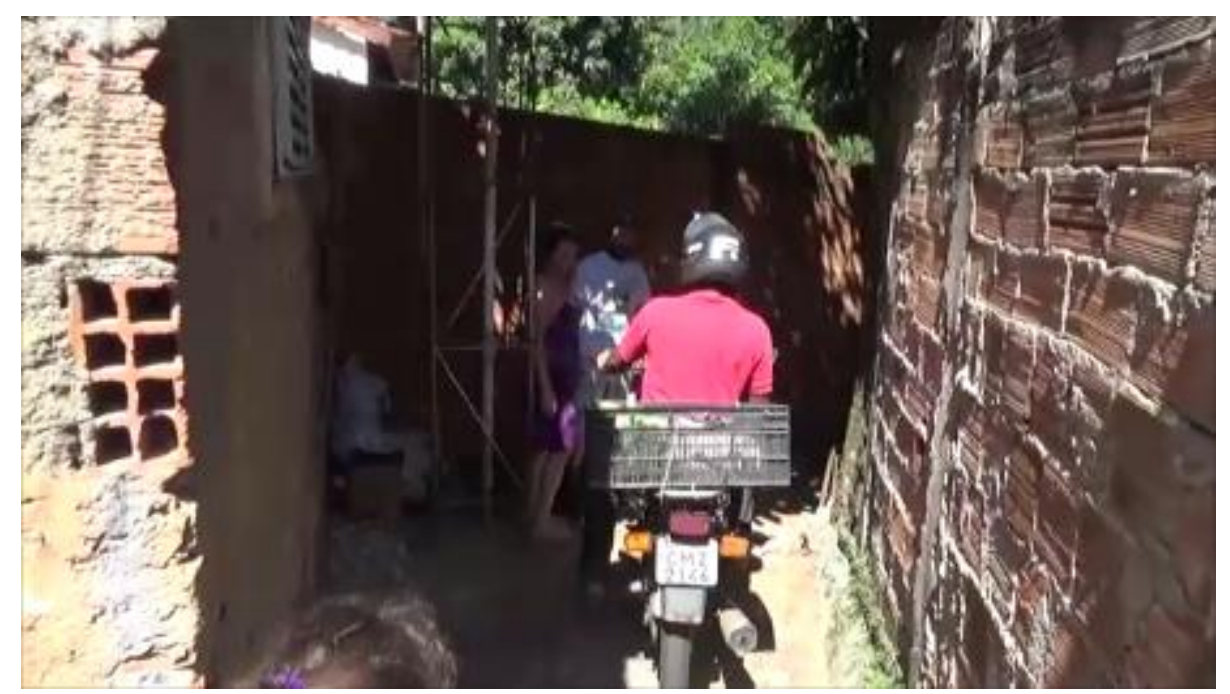

Figura 9: No trieiro Sueli e Jorge encostam-se à torre metálica da caixa d'água para dar passagem ao motociclista. Foto do autor.

A quarta casa fica à direita e parece estar em outro lote, já que o trieiro faz uma curva para o lado esquerdo, segundo Sueli, parte do terreno que a mãe dela vendeu. Com um muro de tijolos não rebocados, a casa possui um pequeno portão azul voltado para o trieiro com uma rampa para entrada de motocicletas. A quinta casa fica à direita e também foi vendida com um recibo feito por sua mãe. Possui na sua parede, que margeia o trieiro, duas janelas de metal e um pequeno portão de metal azul. Na sua frente, tem uma pequena varanda descoberta de aproximadamente 01 metro de largura com o varal de roupas e um poste metálico que dá suporte à caixa d'água. 
Sueli:

Meu pai foi construindo uns barracãozinhos de adobe que ele mesmo fazia aqui (...) pra ele poder alugar. Ele era autônomo, ele não trabalhava. Minha mãe trabalhava com serviços gerais no Estado, então não era lá muita coisa. Aí ele começou a fazer barracãozinhos de aluguel para poder ajudar na vida financeira dentro de casa, se não nós não dava conta não, nós era tudo meninos e não podia trabalhar, só estudar.

Do outro lado do trieiro, à esquerda fica a sexta casa, com paredes rebocadas e pintadas de branco, possui um pequeno quintal cercado por uma tela de metal na frente. Possui um alpendre, duas portas e uma janela cinza. Segundo Sueli, é de uma ex-cunhada dela. Quase em frente, do lado direito, um muro de tijolos não rebocados é a entrada da sétima casa, também vendida pela mãe de Sueli. Na frente, apenas uma porta, uma janela metálica de cor amarela e uma planta trepadeira que cresce de uma lata e disputa o muro com os musgos entre os tijolos por onde a água escorre vinda do telhado da casa.

A oitava casa fica à direita, sua frente possui uma pequena janela de metal e uma entrada. Possui uma pequena e estreita varanda na frente. Os tijolos da parede retratam há quase um metro de altura, as marcas da enxurrada que desce com o surgimento de musgos. Colado a essa parede, outra porta e janela de metal cinza, e uma parede rebocada é a nona casa à direita do trieiro. É de um irmão de Sueli que a ganhou de sua mãe por não ter onde morar.

Essa é a última casa do trieiro e está a poucos metros do córrego, separado por uma pequena área cheia de entulhos de construção e tomada pela vegetação que cresce atrás de um pequeno portão de metal, marca o fim do trieiro. Esse lugar cheio de memórias para as pessoas, vivido e transformado todo dia é uma parte da Ocupação do Jardim Botânico, lugar que retrata em sua forma estética e arquitetônica as trajetórias e as soluções escolhidas por gerações de moradores frente às dificuldades e os desafios do dia-a-dia.

Andar pela ocupação e pelos bairros vizinhos com o Jorge para fazer entrevistas e para ele discutir assuntos do ILOGU com os moradores era sempre uma boa maneira de observar o cotidiano das pessoas, a disposição dos terrenos e das moradias, as reformas, os caminhos que as ligavam e outros detalhes ou pistas a respeito de como aqueles lugares havia sido construídos ao longo do tempo e o que aqueles lugares significavam para as pessoas. 
A casa da Dona Maria chamou atenção. Após uma entrevista emocionada em que nos chamou para ver sua geladeira vazia, apenas com algumas garrafas d'água, duas panelas pequenas, um pote de azeitonas e uma caixa de leite, Dona Maria fez questão de nos levar em cada cômodo de sua casa.

Com as paredes sem pinturas, sem piso, sem portas e sem portal, parecia que esses cômodos, embora já em uso, eram recém-construídos anexos às paredes antigas que se diferenciavam pela pintura desgastada e pelas marcas de grandes infiltrações. A fiação elétrica, improvisada, pendia pendurada sobre nossas cabeças. Em muitas paredes "novas" os cortes onde os fios passam ainda estavam abertos, assim como o lugar onde serão instaladas as tomadas. Sua casa possui uma sala com cozinha em conceito aberto, três quartos e um banheiro.

Dona Maria é viúva, tem mais de sessenta anos e divide a casa com um filho e um neto. No barracão ao lado, também em construção no mesmo lote, mora seu irmão. Cabelos grisalhos bem presos e amarrados atrás da cabeça, com fortes marcas de expressão entre os olhos, sua aparência simples e com a voz trêmula carrega as lembranças da experiência de viver ali há mais de quarenta anos. A aposentada, sempre confiante em Deus e no futuro, normalmente pode ser vista sentada em uma cadeira no portão de sua casa ou cuidado de suas plantas em um pequeno jardim construído em baldes na calçada (Figura 10).

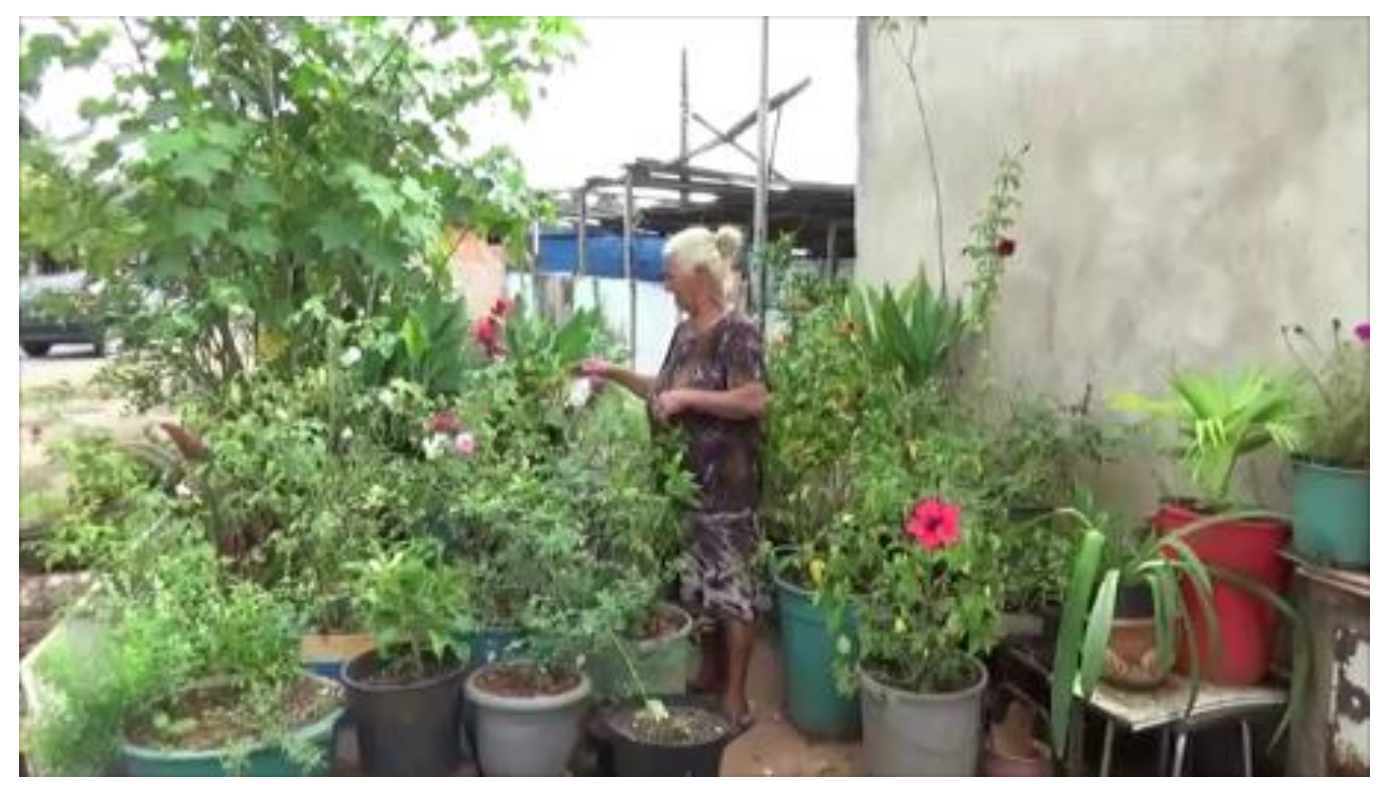

Figura 10: Dona Maria cuidando do jardim em baldes feito por ela na calçada de sua casa. Foto do autor. 
Assim como a de Dona Maria, muitas casas estão em reforma ou em construção. Reformas que parecem se arrastar pela existência desses moradores. Elas constituem o próprio crescimento da ocupação em decorrência do crescimento da família por nascimento ou casamento, em busca de maior conforto ou até mesmo em busca de renda com o aluguel de barracões, ou ainda por separações na família. Alguns lotes, como o apresentado por Sueli, chegam a possuir várias residências familiares, vivendo até três gerações em "conjuntos familiares" que são construídos ao longo do tempo sem o conhecimento da prefeitura, a presença de um arquiteto e muito menos está nos planos da cidade oficialmente planejada.

Dona Maria Aparecida relata como vivia em 1987 quando se mudou para a casa da avó do marido na ocupação com uma filha de quatro meses:

A gente ficou morando na casa da avó dele, na frente da avenida até a gente dar conta de construir um cômodo lá no fundo para gente morar. E assim que nós fizemos, nós fomos para o fundo e lá a gente começou tudo. Fui pra lá e não tinha nem água, não tinha banheiro, não tinha nada. Foi só um cômodo coberto mesmo. Não tinha piso, não tinha nada. Aí, fiquei morando lá, a gente foi aumentando devagarzinho a casa, devagarzinho aumentando e até que agora virou uma residência.

Para Dona Maria Aparecida, o tempo vivido na casa da avó do marido enquanto se construía o cômodo no fundo do quintal não foi considerado como início, e sim o dia em que se mudou para seu cômodo no fundo, que ainda não era, para ela, uma residência. Olhando como um lugar dos sentidos de Augé (2010), cada etapa da construção da residência de Dona Maria Aparecida está relacionada a algum momento de sua vida pessoal, de sua trajetória construída naquele lugar durante todos esses anos, assim como outras casas e outras famílias.

Dona Maria Aparecida se separou e dividiu a casa e o terreno, que era da família do marido. Alguns anos depois a filha também precisou de um espaço no lote,

Agora minha filha mora lá comigo também, a gente fez um cômodo lá para ela porque ela não tinha lugar para morar também, pagava aluguel e aí não estava conse guindo pagar o aluguel, aí fizemos um cômodo para ela e ela mora lá também.

Dona Natalina relembra quando se casou e deixou a casa dos pais em 2003 e confessa o medo de investir na reforma da casa e ser despejada:

Antes eu morava no Parque Amazônia ${ }^{9}$ com meus pais. Aí eu casei e vim para cá. Quando eu vim para cá só eram três cômodos inacabados, três cômodos e um banheirinho. Não tinha nada de cerâmica, era só coberto, as paredes levantadas e

\footnotetext{
${ }^{9}$ Bairro de Goiânia.
} 
coberto. Ai de lá para cá levantamos, construímos e organizamos, e está como está hoje.

Sua casa hoje conta com dois pavimentos, mas o sonho é construir o terceiro para a filha morar. Contudo desabafa:

Eu gostaria que eles dessem a escritura para gente, porque a gente fica assim, você quer melhorar a construção da casa da gente, mas a gente não tem aquela certeza do que aquilo que você vai gastar aqui para melhorar a moradia você vai ser recompensado depois pelo governo. Então eu queria que eles dessem uma solução para gente, se vai indenizar, se vai retirar ou então dá a escritura, dá um documento pra gente.

Zacarias também lamenta a indefinição:

Queria que eles regulamentassem isso aqui. Se regulamentassem eu ia fazer alguma coisa pra gente melhorar a estrutura da gente e viver melhor. A gente fica aqui não sabe se eles vão tirar ou se não vão tirar. A gente não consegue melhorar e fica aqui vivendo de qualquer jeito sendo que a gente podia estar melhor, construir melhor $e$ viver melhor.

Situação semelhante ao período de transição do poder político da cidade de Goiás para Goiânia, quando muitos moradores viveram por anos um sentimento de incerteza e angústia que Tamaso (2007) chamou de "situação crítica", se referindo à ruptura das rotinas habituais da vida dos vilaboenses que produziu uma sensação de insegurança na estrutura social.

Embora muitos vilaboenses não acreditassem na mudança da capital para Goiânia, a mudança gradativa dos prédios públicos, as datas comemorativas como a pedra fundamental em 1933, a mudança provisória em 1935, a mudança definitiva em 1937, e o batismo cultural em 1942, se tornaram uma "situação crítica", efeitos da mudança da capital guardados na memória que "continuam sendo sentidos e reelaborados no decorrer das décadas subsequentes" (Tamaso, 2007:787).

Zacarias é um homem de pele negra, aparentemente com mais de 40 anos que trabalha na construção civil. Quando chegamos à sua casa ele tinha acabado de chegar do trabalho e nos relatou:

Essa é minha casa que eu moro há 15 anos. Tenho 03 filhas, 02 moram comigo. Moro aqui desde 1993. Morava no Tocantins. Aqui é bom para tudo, trabalho, acesso às coisas mais fáceis, não tem nada ruim, pra mim é tudo de bom, meus trabalhos a maioria é aqui perto, isso favorece pra mim (...). Recebi a notificação ontem. O oficial de justiça me ligou, me falou pra eu assinar, me deu umas folhas de papel lá que eu nem li ainda, e falou que eu tenho 15 dias para recorrer. 
Mesmo que em casas humildes e em constante reforma, entre as vantagens de morar ali estão as oportunidades de trabalho, formal ou informal, e o tempo despendido para chegar até ele, assim como a resistência, há outras distâncias como a solidão das periferias, onde à noite as pessoas têm medo, real ou imaginário, de sair de casa devido à violência dos bandidos e à truculência da polícia (Kowarick, 2016).

Para Tamaso (2007:695) “O entendimento do caráter de um lugar ou o seu sentido só pode ser construído por meio da ligação desse lugar com outros lugares", como o Shopping Flamboyant e o bairro Jardim Goiás em relação à OJB conforme mostra o relato de Clodoaldo, que mora e tem uma pequena mercearia no bairro Vila Redenção, próximo à ocupação,

quando eu vim para cá não tinha nenhum prédio, a gente viu a construção do Flamboyant ${ }^{10}$, os trem foi chegando e foi melhorando, então hoje é uma área que está bem localizada, próximo de tudo, então quem não quer uma área dessa? Todo mundo quer uma área daquela, todo mundo quer morar ali, entendeu? Por exemplo, da minha casa até o Flamboyant deve dar um quilômetro, no máximo um quilômetro e meio. Então hoje estão falando em nos tirar de lá, nos tirar por quê? Depois de trinta anos.

A ocupação se faz da vida, das experiências de cada morador e de cada intervenção arquitetônica, afetiva e simbólica nos lugares. Cada cômodo, corredor e cada trieiro foram constituídos para permitir a vida naquele lugar, a permanência e a reprodução. Esse conjunto constitui um registro da história da ocupação que por sua vez, é a história da cidade, das políticas públicas de habitação e construção da capital ao longo de todos esses anos. A escritura, por sua vez, representa a conquista de um sonho, a certeza da permanência e justiça feita frente a todas as dificuldades enfrentadas pelos moradores ao longo desses mais de 60 anos de consolidação da ocupação e de seu entorno.

Para Verás (2016), há constantemente a presença da pobreza em bairros centrais na maioria dos núcleos urbanos que crescem expressivamente, por outro lado, a voracidade do capital imobiliário se revela por um dinâmico movimento de construção, demolição, destruição, reconstrução de áreas já ocupadas com a expulsão dos moradores mais antigos e uma elitização dos espaços onde estão moradores desvalidos.

Contudo, é preciso se considerar que as cidades são construídas por inúmeros atores, ressalta De Certeau (2001), que convivem com as práticas organizadoras da cidade

\footnotetext{
${ }^{10}$ Primeiro shopping de Goiânia que é considerado o maior do Estado de Goiás.
} 
habitada. Essa rede de regras, valores e significados que compõem uma história múltipla e de múltiplos autores é formada em fragmentos de trajetórias e de alterações de espaços. E nesse caso, as experiências antropológicas favorecem um olhar que escapa às totalizações imaginárias do olhar, às práticas estranhas ao espaço "geométrico" ou "geográfico" das construções visuais ou teóricas.

Portanto, as experiências antropológicas expõem as cidades transmutantes ou metafóricas que convivem com a lógica da cidade planejada e visível. A cidade vivida como o contato com os vizinhos que para Robert Park (1987) formam a base mais elementar de associação na vida da cidade, onde interesses e associações desenvolvem sentimento local fazendo da vizinhança, nesse sistema, a base de participação no Governo e do controle político.

\section{Considerações Finais}

Realizar um trabalho etnográfico na cidade onde vivo e atuo como gestor público me proporcionou mais um nascimento nessa capital que também é a casa de milhões de outras pessoas. A cidade que eu conheci na Ocupação Jardim Botânico ainda é desconhecida para muitas pessoas que, como sintetiza Correa (2009), circulam e vivem em suas "ilhas de primeiro mundo", trafegando pela larga Avenida Segunda Radial ou chegando cada vez mais perto pela Avenida Marginal Botafogo, que sob um discurso desenvolvimentista, avança sobre a ocupação, o parque Jardim Botânico e o Córrego Botafogo.

Os lugares que para Tuan (1983), são centros aos quais atribuímos valor, que nos atrai ou nos repelem em graus variados, que é para Augé (2010:51) "simultaneamente princípio de sentido para aqueles que os habitam e princípio de inteligibilidade para quem os observa", um complexo de estruturas conjugadas como acrescenta Tamaso (2007), se tornam ponto de partida para uma maior compreensão da cidade, lançando mão do olhar antropológico para, o que sugere Herzfeld (1991), debate cultural na prática social.

Qual o valor da memória que constitui a identidade dos lugares? Para Tamaso (2012), os lugares são humanizados e humanizantes, construídos fisicamente e simbolicamente. Nessa perspectiva, submeter meu duplo lugar de fala à câmera participante se tornou uma porta de acesso às relações sociais praticadas na ocupação, pois a técnica, adaptada para registrar as memórias dos moradores me permitiu participar 
das dinâmicas coletivas do grupo, primeiro filmando, depois ajudando nos eventos ou planejando junto com eles novas formas de resistência.

O ILOGU, além de ponto de encontro das pessoas que são do pedaço, "uma peculiar rede de relações que combina laços de parentesco, vizinhança, procedência e vínculos definidos por participações em atividades comunitárias”, Magnani, (2012:88), é também uma residência familiar que em outros dias, é apropriado pelos vizinhos para ser palco de suas lutas pelas escrituras durante reuniões e audiências, ou para comer e festejar em eventos da comunidade, fazendo dele um lugar de múltiplos usos, sentidos e significados, uma sinédoque de toda a ocupação.

Aos passos de Jorge, de Sueli e de muitos outros moradores, os casebres de lona, que se tornaram casas de um cômodo, que abrigando famílias se tornaram residências, construídas com muito esforço como descreveram os moradores da OJB, que localizada em um núcleo pioneiro da cidade que abrigou pessoas que vieram construir a capital, se mostrou diante das câmeras como patrimônio dos goianienses. Também mostrou que "a relação da memória com a topografia social não pode mais ser negligenciada na racionalização dos planos diretores urbanos e nas políticas públicas das cidades contemporâneas" (Rocha; Eckert, 2013:217).

Casas ligando famílias pelos caminhos de chão batido e pessoas ligadas pelos hábitos construídos pelas experiências cotidianas da vida na "berada" do Botafogo como lavar roupas no córrego, cultivar alimentos nas hortas ou tomar banho com os amigos em suas águas, gerações coevoluíndo com o ambiente, se criando e modificando o meio. Inspirados pelas formas locais como na construção das lavanderias com suas grandes janelas feitas de grades para recepcionar o sol e quem chegar às casas, e na consolidação dos trieiros que ligam as casas e as famílias, a mata e o córrego, suas memórias e a historia de Goiânia.

Assim como Leite (2007) e De Certeau (2001), tomei os lugares como polissêmicos, possuidores de vários sentidos e constituídos a partir das "estratégias" e das "táticas". Sendo as "estratégias", relacionadas ao poder especializado, que se afirmam como práticas organizadoras da cidade e implicam a construção de uma visão totalizante e homogênea, e as "táticas”, como movimentos heterogêneos e imprevisíveis organizadas 
pela ausência de poder, ou pelos "sem poder", que ocorre no interior de espaços urbanos subvertendo seus sentidos estratégicos.

Infelizmente, o tempo não parece estar a favor dos moradores da OJB. O atual Prefeito Iris Resende do PMDB publicou no dia 06 de setembro desse ano o Decreto $\mathrm{N}^{\mathrm{o}}$ 2618 declarando de "Utilidade Pública" a desapropriação de "todas" as casas de nove ruas nas margens direita e esquerda do Córrego Botafogo para o prolongamento da Avenida Marginal Botafogo. Isso quer dizer que, mais uma vez na história, a qualquer momento a Ocupação Jardim Botânico poderá deixar de existir, assim como as casas de muitos vizinhos da ocupação. Como em tempos remotos relatados por Dona Maria do Bar da Mata, além do Decreto de desapropriação, esse mês o parque queimou com dois incêndios criminosos, ameaçando a mata e as casas que há anos convivem no Jardim Botânico.

"A cidade é o contexto vivido com a pluralidade de alteridades, com aquele que eu não conheço, mas que não é excluído", pois, é exatamente a tolerância para com o estranho que faz a cidade ser cidade. O fazer antropológico, nesse contexto, desperta a consciência de que atividade humana é criada socialmente e não dada pela natureza das coisas, e que as narrativas produzem fóruns de conhecimento entre seus habitantes, interpretam os sentidos de continuidade de uma sociedade, se tornando relevante na área patrimonial (Rocha; Eckert, 2013:223).

Em Goiânia alguns jornais locais dedicam matérias para apresentar o conflito, com destaque para a proposta de Operação Urbana Consorciada apresentada pelo setor imobiliário da cidade e para o Decreto de desapropriação publicado no dia 6 de setembro. Estudantes e movimentos sociais, principalmente os ligados ao urbanismo, realizam atividades locais como oficinas e palestras em busca de um olhar mais aprofundado para as relações das pessoas e dos lugares, e os moradores se mobilizam e continuam resistindo.

Muitos lugares ainda serão modificados para dar espaço ao "desenvolvimento". Estratégias e táticas continuarão transformando nossas cidades nessa dinâmica incessante que é a vida urbana, cidades metafóricas vivendo com cidades planejadas, um ecossistema cheio de lugares repletos de estruturas objetivas, subjetivas e intersubjetivas conjugadas. Como promover um diálogo intersubjetivo entre os atores envolvidos em projetos como 
as Operações Urbanas Consorciadas? Será a memória, patrimônio imaterial de um povo, capaz de mudar o foco das intervenções urbanas para a valorização social ao em vez de apenas a valorização estrutural dos lugares? Como evitar a gentrificação nas dinâmicas urbanísticas dos bairros? São muitas as perguntas que surgem para os estudiosos, para os planejadores urbanos e para os moradores da Ocupação Jardim Botânico há espera de respostas.

Em campo, me tornando antropólogo e me fazendo gestor público, atividade onde o planejar tem sido colonizado por saberes e discursos que escamoteiam a segregação social urbana, foi por meio da câmera participante, isto é, por meio da intersubjetividade que vi as ruas, calçadas, árvores, casas e quintais ganharem formas talhadas pelas memórias, ganharem outros sentidos que se misturam com a história das pessoas, e as pessoas com a história dos lugares.

\section{Referências Bibliográficas}

ACHUTTI, Luiz E. R. Fotoetnografia: um estudo de antropologia visual sobre cotidiano, lixo e trabalho. Tomo Editorial; Palmarinca, Porto Alegre, 1997.

AUGÉ, Marc. Por uma antropologia da mobilidade. Tradução Bruno César Cavalcante, Rachel Rocha de Almeida Barros; revisão Maria Stela Torres B. Lameiras; EDUFAL, UNESP, Maceió, 2010.

ALVAREZ, Gabriel O. Os momentos interpretativos da antropologia e a antropologia visual compartilhada. Iluminuras, v. 14, n.32, p. 43-54, jan./jun. Porto Alegre, 2013.

ARANTES, Germana F. Intervenções Urbanas: rumo à cidade neoliberal, Appris, Curitiba, 2015.

ARAÚJO, Juliano J. A realização de documentários por comunidades indígenas: notas sobre o projeto Vídeo nas Aldeias. Intexto UFRGS, n. 26, p. 151 - 169. Porto Alegre, jul. 2012.

BARBOSA, Maria J. S. Globalização, novas relações econômicas e impactos em cidades brasileiras. In Metamorfoses sociais e políticas urbanas, Ramos, M., H., R., (org), p. 85 - 111, DP\&A, Rio de Janeiro, 2002.

CORREA, Elaine A. L. A dinâmica socioespacial da região sudoeste de Goiânia: uma análise da produção e valorização do bairro Celina Park. Dissertação de Mestrado UFG, Goiânia, 2009.

CHAUL, Nasr F. A construção de Goiânia e a transparência da capital. $2^{\mathrm{a}}$ Ed. Goiânia, Editora da UFG, 1999.

DAMATTA, Roberto. Relativizando: uma introdução à Antropologia Social. Rocco, Rio de Janeiro, 2010. 
DE CERTEAU, Michel. A invenção do cotidiano: artes de fazer. $6^{\text {a }}$ Ed.Vozes, Petrópolis, 2001.

FREYRE, Gilberto. Sobrados e mocambos: introdução à história da sociedade patriarcal no Brasil. Record, 10a. Edição, Rio de Janeiro, 1998.

FREITAG, Bárbara. A Megalopolização das cidades latino-americanas na virada do milênio In Teorias da Cidade, Papirus Editora. São Paulo, 2006.

GIDDENS, Anthony. A constituição da sociedade; tradução Álvaro Cabral, $3^{\circ}$ Ed. São Paulo. Editora WMF Martins Fonte, 2009.

GUPTA, Akhil. FERGUSON, James. Mais além da "cultura": espaço, identidade e política da diferença. In O espaço da diferença, Arantes, Antônio, A. (org.). p. 30 - 49, Papirus Editora, Campinas SP, 2000.

HARVEY, David. Cidades Rebeldes. Do direito à cidade à revolução urbana. Tradução: Jeferson Camargo. Martins Fontes, São Paulo, 2014.

HERZFELD, Michael. A place in history: social and monumental time in a Cretan Town. In: The Anthropology os Space and Pace: locating culture/ edited by Setha M. Low and Denise Lawrence-Zúñiga. Blackwell Publishing, 1991.

HOWLETT, Michael, RAMESH, M.; PERL, Anthony. Política Pública: seus ciclos e subsistemas: uma abordagem integral. Rio de Janeiro, Elsevier, 2013.

JACOBS, Janes. Morte e vida de grandes cidades. Martins Fontes, São Paulo, 2003.

KOWARICK, Lúcio. Cortiços: reflexões sobre humilhação. In Pluralidade Urbana em São Paulo: vulnerabilidade, marginalidade, ativismos; Organização de Lúcio Kowarick e Heitor Frugoli Jr., 1ª Edição, São Paulo, Editora 34, São Paulo, p. 171 - 193, 2016

LAPERRIÈRE, Anne. Os critérios de cientificidade dos métodos qualitativos. In A Pesquisa Qualitativa: Enfoques epistemológicos e metodológicos, Vários Autores. Vozes, Petrópolis, RJ, 2008.

LEITE, Rogério P. Contra-usos da cidade: lugares e espaço público na experiência urbana contemporânea, $2^{a}$ Edição, Editora UNICAMP, Campinas, SP; Editora UFS, Aracaju, SE, 2007.

LEITE, Carlos AWAD, Juliana C. M. Cidades sustentáveis, cidades inteligentes: desenvolvimento sustentável num planeta urbano, Bookman, Porto Alegre, 2012.

LÉVI-STRAUSS, Claude. Tristes Trópicos; tradução Rosa Freire D’aguiar, São Paulo, Companhia das Letras, 1996.

LINFIELD, Susie. The Cruel Radiance: Photography and political violence - Paperback edition, Chicago, 2012.

MACHADO, Laís A. Uma cidade no sertão; In Formas e tempos da cidade, Manuel Ferreira Lima Filho, Laís Aparecida Machado (Orgs), p. 49 - 88, Editora da UCG; Cânone Editorial, Goiânia, 2007.

MAGNANI, José G. C. A antropologia urbana e os desafios da metrópole. Tempo Social. Revista de Sociologia da USP, Vol. 15, N. 1, p. 81-95, São Paulo, 2003. 
MAGNANI, José G. C. Da periferia ao centro: trajetórias de pesquisa em antropologia urbana, Editora Terceiro Nome, São Paulo, 2012.

MIRANDA, Ana P. M. OLIVEIRA, Marcella B. PAES, Vívian F., Antropologia e Políticas Públicas: notas sobre a avaliação do trabalho policial. Cuad. Antropol. Soc, Buenos Aires, n. 25, jul. 2007.

NATAL E SILVA, Colemar. Goiânia: origens, projetos, concretização. Goiânia, Editora da UFG, 1993.

OLIVEIRA, Adriana M. V. PEIXOTO, Elane R. Estudos de Bairros: entre a arquitetura e a história. Revista Mosaico, v. 2, n. 1, p. 59 - 67, jan - jun, Goiânia, 2009.

PARK, Robert E. A cidade: sugestões para a investigação do comportamento humano no meio urbano. In Velho, Octávio Guilherme (org.). O fenômeno urbano. Guanabara: Rio de Janeiro, $4^{\text {a }}$ ed., p. 26 a 67, 1987.

PASTERNAK, Suzana Favelas: fatos e boatos, In Pluralidade Urbana em São Paulo: vulnerabilidade, marginalidade, ativismos; Organização de Lúcio Kowarick e Heitor Frugoli Jr., 1ª Edição, São Paulo, Editora 34, São Paulo, p. 83 - 110, 2016.

QUIJANO, Aníbal El fantasma desdesarrollo em América Latina. Rev. Venez. De Econ. y Ciencias Sociales, Vol. 6 N. 2 (mayo-agosto), p. 73-90, 2000.

RIBEIRO, Gustavo L. Ambientalismo e desenvolvimento sustentado: nova ideologia/utopia do desenvolvimento, Ciência e Informação, Vol. 21, N. 1, Brasília, 1992.

RIBEIRO, Maria E. J. Infraestrutura verde, uma estratégia de conexões entre pessoas e lugares: por um planejamento ecológico para Goiânia. Tese (Doutorado) - Universidade de São Paulo, São Paulo, 2010.

ROCHA, Ana L. C.; ECKERT, Cornelia. Etnografia da Duração: antropologia das memórias coletivas em coleções etnográficas. Marcavisual, Porto Alegre, 2013.

SEGURA, Ramiro. Los sentidos del lugar. Temporalidades, relaciones sociales y memórias em um barrio segregado de La Plata (Argentina). Sociedade e Cultura, v. 16, n. 1, p. $59-68$ jan./jun. Goiânia, 2013.

SHIVA, Vandana. Monoculturas da mente: perspectivas da biodiversidade e da biotecnologia, São Paulo, Gala, 2003.

STAM, Robert. Introdução à teoria do cinema. In: Coleção Campo Imagético, Campinas, SP, Papirus, 2003.

TAMASO, Izabela M. Etnografando os sentidos do lugar: pintando, declamando e cantando a cidade de Goiás. In: TAMAZO, I. M., LIMA FILHO, M. F. Antropologia e Patrimônio Cultural: trajetórias e conceitos, Brasília: Associação Brasileira de Antropologia, pp. 219 - 244, 2012.

TAMASO, Izabela M. Em nome do Patrimônio: representações e apropriações da cultura na cidade de Goiás. Tese (Doutorado) - Universidade de Brasília, Brasília, 2007.

TUAN, Yi-Fu. Espaço e lugar: a perspectiva da experiência, tradução Lívia de Oliveira, DIFEL, São Paulo, 1983. 
VELHO, Gilberto. Um antropólogo na cidade: ensaios de antropologia urbana, Rio de Janeiro, Zahar, 2013.

VERÁS, Maura P. B. Segregação e alteridade na metrópole: novas e velhas questões sobre cortiços em São Paulo, In Pluralidade Urbana em São Paulo: vulnerabilidade, marginalidade, ativismos; Organização de Lúcio Kowarick e Heitor Frugoli Jr., $1^{\text {a }}$ Edição, São Paulo, Editora 34, São Paulo, p. 111 - 140, 2016.

ZUKIN, Sharon Paisagens Urbanas pós-modernas: mapeando cultura e poder. In Arantes, Antônio Augusto (org). O espaço da diferença. Papirus, p. 80 - 103, Campinas, 2000 . 